\title{
0 Florescimento da Cana de Açúcar
}

Jayme Rocha de Almeida

Prof. Cat. da Cad. de Tecnologia

\section{Otavio Valsecchi}

Assistente da Cad. de Tecnologia

Frederico Pimentel Gomes

Assistente da Cad. de Matemática

Escola Superior de Agricultura

"Luiz de Queiroz", Universidade

de S. Paulo

\section{INDICE}

Variedade da cana .......60

Idade $d a$ cultura ........ 64

Sanidade da cultura ..... 66

Umidade do solo ........ 68

Natureza e caráter do solo 72

Tratos culturais ........ 72

Adubação ............ 73

Altitude e latitude ..... 73

Análise estatística ........74

Análise estatística dos da- dos da variedade Co.

$285 \ldots \ldots \ldots \ldots \ldots \ldots .87$

Análise estatística dos da-

dos da Variedade Co.

$312 \ldots . . . . . .69$

Análise estatistica dos da-

dos da Variedade Tuc.

$519 \ldots \ldots \ldots \ldots \ldots \ldots . . .61$

Resumo e interpretação da

análise estatistica ...... 92

Bibliografia $\ldots \ldots \ldots \ldots \ldots .115$ 
Acreditou-se, por muito tempo, que as flores da cana de açúcar eram estéreis, porém, ao se descobrir o contrário, se iniciou nas distintas estações experimentais espalhadas pelo mundo todo, uma era de pesquisas no sentido de produzir canas de sementes, para a obtenção de novas variedades.

Os resultados destas pesquisas não se fizeram esperar. Gracas as êxito alcançado nestes estudos, hoje se contam por centenas as novas variedades de cana obtidas por cruzamentos. Embora o problema seja de solução bastante difícil, em algumas destas estaçóes procura-se controlar o florescimento da cana por qualquer meio para aumentar as possibilidades de novos e mais numerosos cruzamentos, uma vez que a cana não floresce comumente nas regiōes em que se localizam as referidas estaçðes.

A marcante importância econômica adquirida nos últimos anos pelas novas variedades de cana produzidas pelos processos de cruzamento, torna de interêsse coletivo qualquer informaçăo sôbre a questão do florescimento da cana de açúcar.

A razão dessa asserção encontra apóio ponderável, se justificarmos que o estudo do florescimento da cana deve preceder sempre aos trabalhos de cruzamentos.

Foi pensando assim e tendo em vista estudar a influência do florescimento diretamente na indústria do açúcar, que resolvemos iniciar no ano em curso um estudo sistemático dêsse fenômeno tåo frequentemente observado nos canaviais do municipio de Piracicaba. O nosso desejo é.tão sòmente comeşar a coordenar fatos e observações locais para que, dentro de alguns anos consecutivos de pesquisas, possamos dispor de suficiente número de dados que nos permitam apreciar com mais justeza as principais causas determinantes do florescimento da cana de açúcar e os efeitos dêle decorrentes, tanto na composição da cana como na fabricação do açúcar.

O presente trabalho é uma contribuição ao assunto, dando a publicidade as observações que a Seção de Quimica Tecnológica, recentemente criada na Escola Superior de Agricultura "Luiz de Queiroz", conseguiu obter em 1944 e que serão continuadas e possivelmente completadas nos anos vindouros.

Como a cana de açúcar é cultivada sob as mais variaveis condiçóes climáticas no mundo inteiro, encontram-se grandes variações nas causas ligadas ao florescimento. Estas causas que governam o florescimento da cana de açúcar, apesar do grande número de estudos já realizados, indiscutivelmente, ainda permanecem em dúvida. As nossas observações constantes da presente publicaçáo, somadas às obtidas por diferentes auto- 
les eni diferentes regiøes açucareiras, poderão contribuir para trazer alguma luz sôbre o assunto. Ademais, somos de parecer que o assunto é regional e que, portanto, deve ser examinado separadamente em cada zona onde se cultiva a cana extensivamente.

O florescimento das plantas é um processo natural que marca o ponto final do seu crescimento normal ou periodo vegetativo. Como êsse fenômeno é normalmente dependente das variações climatéricas, êle geralmente ocorre em cada planta e em cada lugar em uma determinada época do ano. A tendência ao florescimento não constitui, portanto, nenhum privilégio especial de boas ou de más variedades de cana.

A cana de açúcar não faz exceção a esta regra geral, embora a maneira segundo a qual ela floresce seja bastante fortúita, conforme sabem todos que estejam familiarizados com a sua cultura.

A maneira mais racional de encarar o florescimento é admitir que êle representa o sinal de que o colmo atingiu o têrmo do seu crescimento e náo ainda a maturação, como geralmente se admite, uma vez que por maturação se conceba o estado de máxima riqueza sacarina da cana. Nåo é, pois, inteirainente correto admitir-se que o florescimento é mais característico de canas que amadurecem mais facilmente, visto como nem sempre isso se observa na grande prática. Um caso típico é o que se dá com a CP 27-139 em Piracicaba. Embora seja uma variedade de maturaçáo tardia, é a que primeiro floresce nesta zona e geralmente a sua intensidade atinge a $100 \%$. A POJ 213, de maturação precoce, só muito raramente aquí floresce e em muito pequena intensidade.

Uma vez iniciada a formação do escapo floral (borracha) pelo desenvolvimento da gema terminal, que de folhifera passou a florifera, a cana práticamente não cresce mais no sentido do seu comprimento, sejam quais forem as condições mesológicas e climatéricas posteriores. Pouco ou nenhum aumento de pêso se dá depois do florescimento e se as condiçóes são em favor do periodo de paralização (diminuição do calor e da evaporação), não há ponderável deterioração do caldo.

Florescidas e conservadas de pé, sem cortar, tais canas só começam a diminuir de pêso depois de algumas semanas e, assim mesmo, esse fenômeno está diretamente ligado à variedade. Dai por diante murcha e seca a parte superior do colmo junto com a ráquis da inflorescência. Esta perda de pêso pode atingir ao máximo de $46 \%$. Estas condições tôdas são, entretanto, condicionadas às variedades, pois umas começam à perder 
Anais da E. S. A. "Luiz de Queiroz»

peso muito mais depressa que outras, porque o seu escapo floral seca mais fácilmente. A variedade POJ 2725, a julgar apenas pelos ensaios refratométricos, pode ser considerada madura quando floresce, deteriorando-se, a seguir, muito ràpidamente.

Sobrevindo um periodo de chuva mais ou menos prolongaco, as canas florescidas emitem brotos laterais às expensas da reserva sacarina acumulada nos colmos. Igualmente essa capacidade náo é a mesma para as diferentes variedades de cana. Há variedades que apresentam maior tendência à brotaçăo lateral que outras.

Pela brotaçăo lateral, após o florescimento, o prejuizo causado elevado, porquanto, além da reduçáo da tonelagem por área, diminui a \% de sacarose e eleva-se a de redutores, com acentuada diminuiçáo da pureza do caldo. $O$ açúcar provável \% de cana e no caldo reduz-se consequentemente.

Por estas razóes os usineiros consideram boa prática cortar e moer primeiro os talhóes de canas florescidas, mesmo que a sua maturação não se tenha completado. Outra causa determinante desta praxe é que, por via de regra, as nossas usinas enfelxam as canas cortadas para facilitar o carregamento dos veículos no campo. Ora, como o amarrilho dos feixes é feito com a ponta da cana, uma vez florescida esta, o enfeixamento torna-se dificil por falta de ponta, obrigando mesmo, segundo - grau de intensidade do florescimento, a uma mudança no sistema de carregamento, que se fará com canas a granel, mudança de trabalho esta que trará como consequência um possivel cncarecimento da operação.

Se não chover o florescimento não causa prejuizo que não seja 0 da diminuição da tonelagem por área, e esta mesma só se verifica em parte e se as canas florescidas forem mantidas sem cortar após longo tempo a contar da emersão do escapo floral. A perda de tonelagem por área nas canas florescidas é muitas vezes compensada pelo aumento de açúcar produzido por tonelada de cana.

O tempo gasto para emergir completamente a inflorescência varia de 2 a 3 semanas, segundo o tamanho da bandeira, flecha ou pendão, com a variedade, com o tempo de plantação e, muito provàvelmente, também com as condições ambientes. Neste particular, as nossas observaçōes éste ano foram muito incompletas e prejudicadas devido às irregularidades climatéricas verificadas. Poucas variedades permitiram observaçóes completas e corretas. Outras variedades, como consequencia da seca que assolou Piracicaba (vide Dados Meteorológicos), 
uma vez iniciada a emissão do escapo floral, depois de alguns meses ainda a inflorescencia năo havia sofrido emersăo total. Secava, apodrecia e quebrava-se pela ação do vento sem se completar.

Uma vez emergida a inflorescência, as flores, por via de regra, se abrem de cima para baixo. O tempo de abertura da primeira flor relativamente á emersăo da inflorescência varia considerávelmente : em algumas variedades as flores se abrem no momento da emersão; outras, como a POJ 2714, quando a emersáo está na metade, enquanto que terceiras, como a POJ 2725, se abrem depois que terminou a emersáo. Parece, entretanto, que êsse fato năo é caracteristico especifico. $O$ temps da abertura se verifica possivelmente pela madrugada.

Verificamos os seguintes fatos gerais êste ano em Piracicaba no que diz respeito ao florescimento da cana de açúcar:

Inicio do florescimento .. 25 de Maio;

Ordem do aparecimento

do escapo floral ........ Co. 285; P 33-29; Kassoer listada;

Kassoer verde; Tuc. 519; Co. 312. CP 27-139; CP 29-137; POJ 2883; S 109; S 164; POJ 2735; S 563: F 29-7; S 42; CP 29-291; CP 29-320; Kassoer; US 16-94;

Temp̣ de emersão total da inflorescencia $\ldots \ldots \ldots$.
Co. 285 - de 13 a 17 dias foi 0 tempo dominante;
11 dias o minimo;
27 dias o máximo;

Co. 312 - de 15 a 23 dias foi 0 tempo dominante;

15 dias o minimo;

28 dias o máximo;

Tuc. 519 - de 17 a 21 dias foi 0 tempo dominante;

15 dias o minimo;

26 dias o máximo;

CP 27-139 - de 16 a 21 dias foi o tempo dominante;

15 dias o minimo;

27 dias o máximo.

As observaçóes nas demais vatiedades ficaram prejudicadas pela sêca. 
Intensidade do floressiinento

$100 \%$ Co. 285; P 33-29; Tuc. 519; Co. 312; CP 27-139; CP 29-137; S 109; S 164; S 563; S 42; US 16-94;

95\% F 28-7;

$70 \%$ CP 29-291;

35\% CP 29-320;

$30 \%$ Kassoer Listada;

$15 \%$ Kassoer Verde;

$10 \%$ POJ 2883;

5\% Kassoer;

$1 \%$ POJ 2735.

Năo floresceram este ano. POJ 2727; POJ 36; POJ 213; POJ 161; POJ 234; POJ 2714;

Co. 290; Co. 281; Co. 213;

Taquara, Riscada e outras.

Emitiram brotos laterais . CP 29-137.

Todas as canas florescidas apresentaram brotos laterais superiores em número médio de 2 , minimo de 1 e máximo de 4, cujo comprimento variou de $20 \cdot 2 \cdot 65$ centimetros.

Tuc. 519; Co. 312; Co. 285.

Apenas começaram a apresentar brotaçáo lateral.

As demais variedades, enquanto duraram os nossos trabalhos nåo apresentaram esse caráter.

Estas observaçōes foram tomadas antes de se iniciar 0 perfodo de chuvas.

Conforme se pode deduzir dos dados acima por nós obtidos, as variedades de cana diferem năo só em intensidade, como na sua maior ou menor tendéncia ao florescimento, maior ou menor tendencia a brotação lateral, como no tempo de florescer.

thste ano o florescimento nåo foi abundante como nos anos anteriores no município de Piracicaba. Resultoa dal grande di- 
ficuldade nas observaçóes de cada variedade, pois variedades que ordinàriamente floresciam intensamente aqui, êste ano, em consequéncia da irregularidade do clima năo floresceram ou floresceram muito pouco.

Năo devemos nos esquecer que o efeito das mudançás cliinatéricas é notadamente verificado nas regiöes sub-tropicais sóbre a composição do caldo da cana. Este o nosso caso. Ao se aproximar o inverno nas canas não florescidas a \% de sacarose sofre maiores alteraçōes que nas canas florescidas, pois nestas, por via de regra, as mudanças climatéricas são menos perceptiveis, uma vez que estas canas paralisaram já 0 seu periodo de crescimento.

Entretanto, quando brotam, dá-se um aumento sensivel de redutores devido à inversão de sacarose. Isso se dá para que o açúcar invertido formado seja encaminhado para os gomos verdes da ponta onde, aumentando o poder isotónico dos líquidos celulares, promoverá o crescimento dos brotos laterais. Naturalmente, a intensidade desta inversão está em correspondência com a queda da pureza do caldo.

Não havendo brotação lateral e se o tempo correr favorável, o florescimento praticamente năo causa prejuizo algum, pois a pequena reduçăo de pêso em tonelagem por área, isso mesmo quando esta se verifica, é contrabalançada pela elevação da percentagem de açúcar.

Infelizmente, por̈ razóes independentes da nossa vontade. lomos obrigados a interromper as nossas pesquisas ao se iniciar o período de chuvas, de tal maneira que êste ano não pudemos aquilatar das possiveis diferenças existentes na composição entre as canas florescidas e brotadas, florescidas $e$ não brotadas, comparativamente à das canas não florescidas e brotadas, não florescidas e nåo brotadas.

Hoje considera-se que o principal fato qae se insurge contra o floréscimento é o da paralisaçáo do crescimenta da cana. Se èsse crescimento năo é recomeçado nada há que recear. Porém, quando devido a favoráveis condições de umidade, as gemas terminais da ponta das canas florescidas brotam, o açúcar armazenado é usado pela planta e o coeficiente glucósics aumenta em detrimento do caldo, cuja composição náo é; prirém, muito afetada. Além disso, a deterioração do caldo só se manifesta com intensidade quando o tôpo da cana começa a murchar e dai, morre, seca, avermelha ou apodrece.

Admite-se, comumente, entre os estudiosos, que a \% de redutores é distintamente mais baixa nas canas florescidas, missmo quando estas começam a deteriorar: que as canas florescidas contêm mais cinzas que as não florescidas; que a riqueza 
Anais da E. S. A. «luiz de Queiroz"

da cana florescida como a pureza do caldo aumentam depois que a inflorescência emerge e isto acontece até 2 a 3 meses depois de completo o florescimento, numa proporção de 3 a $4 \%$ em sacarose e de 5 a $8 \%$ em pureza. Não obstante, os dadcs que obtivemos êsse ano, conforme se depreende das análises tstatísticas adeante efetuadas, nem sempre nos conduziram a esses resultados.

Naturalmente, nem todas as variedades de cana se comportam dessa maneira. A POJ 2725 é típica como cana que se torna passada com facilidade depois de florescida. Assim, cêrca de 1 mês depois de florescida perde em sacarose e reduz-se a pureza do seu caldo, onde se nota aumento rápido dos açúcares redutores; a Co. 285 melhora pouco depois de florescer, talvez porque floresce muito cédo, começando a se deteriorar depois de 3 meses de florescida; a POJ 2878 deteriora-se depois de 5 meses.

Mas, como os fatores climatéricos não podem ser controlados pelo homem é preferivel não aguardar aquéle possível enriquecimento do caldo da cana florescida e iniciar o corte pelos talhóes que acusarem maior \% de canas florescidas. Esse é um clos pontos que pretendemos esclarecer para o futuro, para o bem do trabalho das usinas, isto é, determinar com precisão cuais as variedades de cana que uma vez florescidas têm a sua composição estabilizada, melhorada ou prejudicada, qual a extensão dessa alteraçáo e em que tempo se verificam tais alteraçóes.

Diante da incerteza que ainda perdura pode-se concluir que $\supset$ florescimento da cana é um fator indesejável para o usineiro devido a cessaçáo do crescimento do colmo e possibilidade de elevada inversăo, o que a torna mais suscetível de morrer que a cana năo florescida. Porém é um fator de grande valor para o geneticista que trabalha em cruzamentos para obtenção de novas variedades. Acresce ainda que as canas tlorescidas náo se prestam para mudas porque, além de outras razós, é de se acreditar que usando os colmos florescidos para muda, favorece-se à tendencia ao florescimento.

A opinižo mais ou menos generalizada dos usineiros e dos agricultores práticos, em geral, sobre o florescimento da cana de açucar é que ele é sempre prejudicial, sejam quais forem as causas determinantes do seu aparecimento. O pensamento mais comum entre éles é que o florescimento mostra o declinio da sua lavoura, pois acreditam ser esse fenómeno 0 marco inicial e visitel da degenerescéncia da cana, que se torna ćca e sêca. 
Por que razăo esse modo de encarar tal fato?

Se na verdade assim acreditam năo sabem entretanto afirmar e demonstrar porque, estribando-se em argumentos técnicos ou cientificos irrefutáveis. Até certo ponto, contudo, os usineiros e os agricultores práticos que olham o florescimento da cana como uma condiçáo desfavorável, têm razăo. pois são apoiados em fatos verificados na natureza.

Assim, por exemplo, acham êles que a frequência e a intensiuade do florescimento atualmente são muito mais acentuadas que antigamente, quando no Estado de Săo Paulo só se cultivavam variedades grossas como a Caiana, a Riscada, ¿ Manteiga, etc. A justificaçáo dessa causa que desperta sempre tanta preocupaçáo ao leigo pode ser apresentada com clarecia meridiana.

Aquelas antigas variedades, sendo propagadas ou reproduzidas assexualmente ou por melos puramente vegetativos, por estacas, olhaduras, pontas ou roletes, desde épocas muito remotas, foram perdendo em grau apreciável e crescente a sua capacidade para produzir flores e sementes férteis, chefando mesmo a năo florescer por completo. assim que se encontram variedades que nunca florescem numa regiăo açucareiru onde são nativas ou para onde foram introduzidas há centenas de anos, quando floresciam em outras zonas sob condições especiais de ambiencia ou quando sob a açăo de um mal grave que as ameaçasse de extinçăo. Como exemplo, podemos citar a cana Ubá que floresce na América Central, enquanti) que em Natal (Africa) e nos Estados centrais e sulinos do Brasil, só muito raramente floresce. por isso que a irtensidade de florescimento encontrada em diferentes variedades de cana varia em larga escala.

$E$ porque as atuais variedades florescem tanto e com tanta frequência em Săo Paulo ? Degenerescência, castigo celestie, mau agouro?

Nada disso. Ultimamente, em virtude do número senıpe crescente de "seedlings" novos de cana que têm substituidu aquelas variedades antigas e grossas nos campos de cultura, verifica-se que o florescimento aumenta dia a dia. Isso se dá porque essas novas variedades cultivadas entre nós, são tódas progênies de espécies que retiveram a sua faculdade de produzir flores férteis. Elas são hibridos originários de cruzamentos sucessivos realizados em datas bem recentes. Sendu produzidas por semente, é natural, portanto, que elas tenham muito mais aptidăo para florescer e produzir sementes, principalmente se encontram condiçóes mesológicas e climatéricas 
favoráveis, pois herdam, naturalmente em maior ou menor grau, êsse característico dos ancestrais, que só foram usados nos trabalhos de cruzamento pelo fato de florescerem bem. Vem confirmar as nossas palavras o fato que se verificou aqui ésse ano: todos os "seedlings" nacionais do I. A. C. existentes em cultura em Piracicaba floresceram com intensidade de $100 \%$ e foram os que primeiro. iniciaram a emissão do escapo floral. Quando iniciámos os nossos trabalhos já 98\% destes "seedlings" estavam completamente florescidos.

Com o continuar do tempo, pela maneira ininterrupta de reprodução vegetativa, essa pronunciada.tendéncia ao florescimento deve ir diminuindo progressivamenie até se tornar igual à das antigas variedades que existiam em São Paulo. Logo, a frequência do florescimento e a sua intensidade não deyem constituir motivos de séria apreensāo do usineiro e do agricultor prática.

Outra causa do temor provocado pelo florescimento repousa em observações ou opiniões colhidas alhures.

Assim, é conhecido o fato de que em certas regiões açucareiras onde a cana cresce fora das condições tropicais que lhes são propícias, como no norte da India, no sul de Queensland, em Natal (Africa) e na Luisiana, o florescimento é impedido em grande extensão. Na Luisiana as variedades atualmente cultivadas raramente atingem o estágio de florescimento, mas em 1941, as variedades CP 29-103, CP 29-116 e CP 29-120 mostraiam extensivo florescimento incipiente e em alguns casos uma considerável \% de colmos produziram flores completamente desenvolvidas. $\mathbf{E}^{2}$ de se supor que a causa tenha sido a anormal temperatura elevada oxatamente outubro naquela região açucareira, o que evidentemente, de pássimas consequências. Na fndia, principalmente, o florescimento é olhado como um verdacieiro desastre ou flagelo, chegandu a população inteira de certas aldeias a abandoná-las, pois o florescimento da cana, para o indiano inculto, é o prenúncio de sêca, seu implacável inimigo, que traz consigo a fome e a miséria.

Para REYNOSO, incếndio no canavial e florescimento são sinônimos, pois os prejuizos que ambos causam são os mesmos; os cubanos consubstanciam a sua opinião sôbre o florescimentc da cana num velho rifáo popular - año de guín año ruin.

Alguns autores asseveram que em algumas variedades de cana $10 \%$ de florescimento correspondem a uma diminuição de 1: tonelada de açúcar por alqueire, coisa com que não concorciamos em absoluto. REYNOSO vaí mais além e afirma que cada dia que pasșa pode o florescimento ocasionar a inversão da 


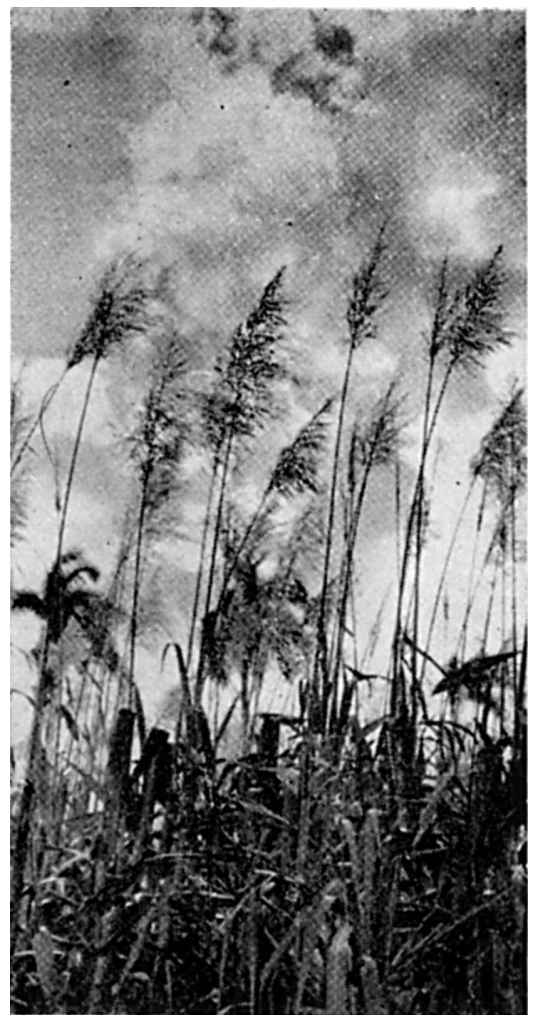

Fig. 1 - Fotografia de um canavial florescido 


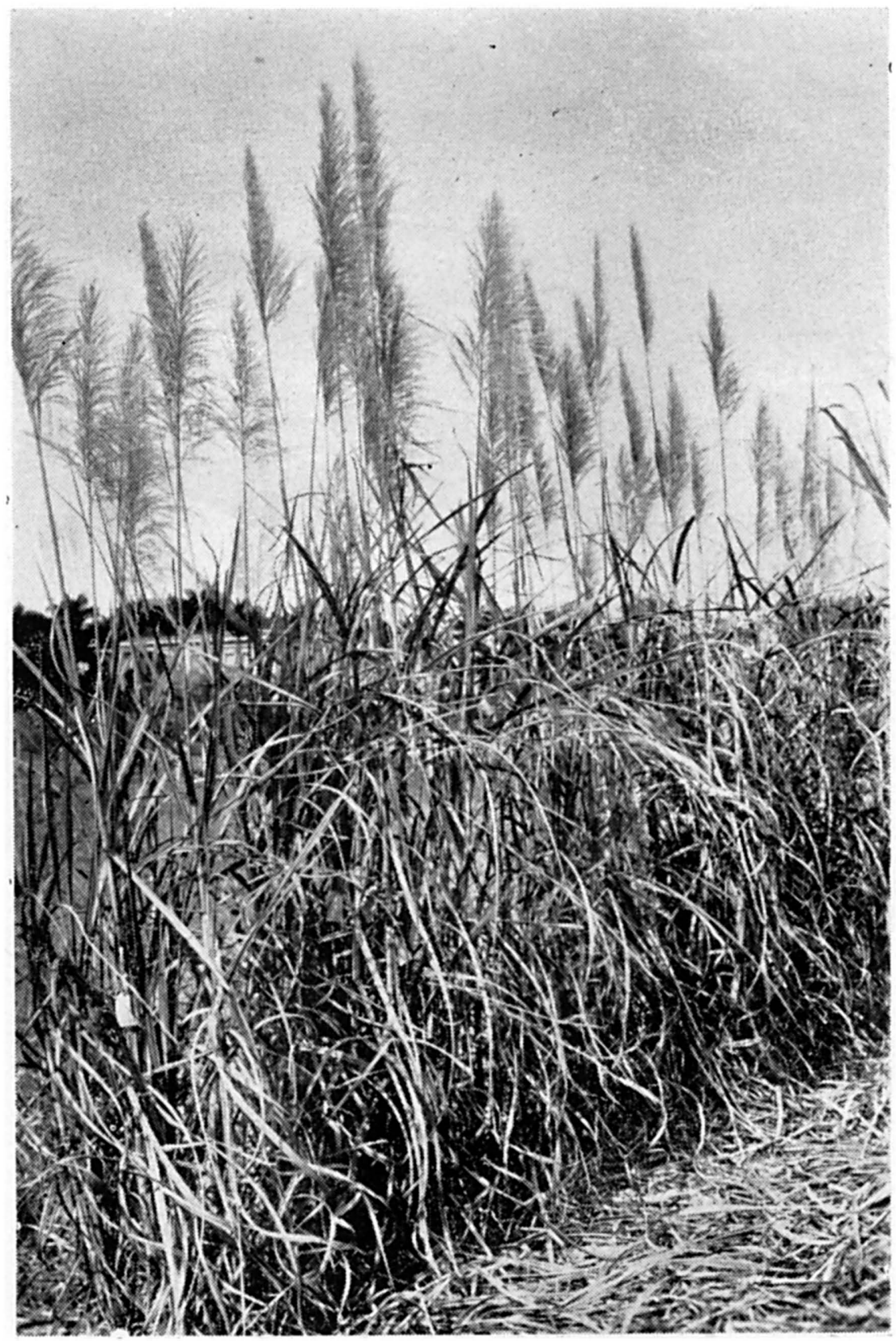

Fig. 2 - Variedade Co. 312 (Original) 


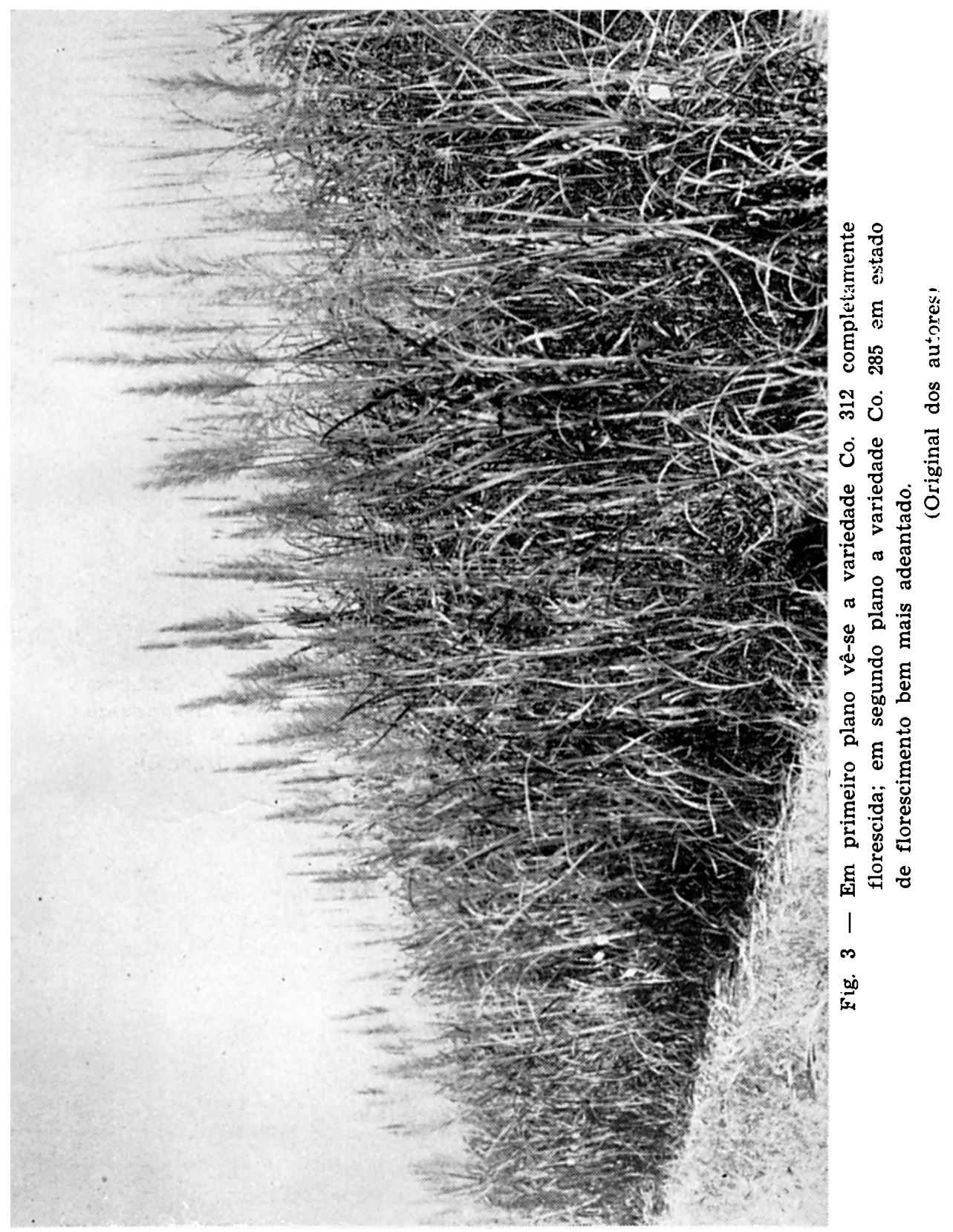




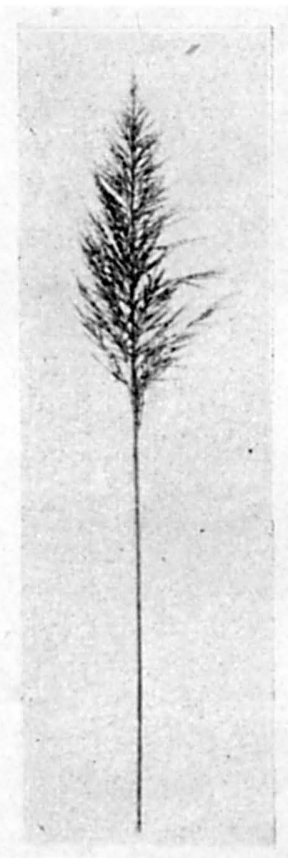

Fig. 4 - Inflorescência da variedade CP. 29-137 (Original

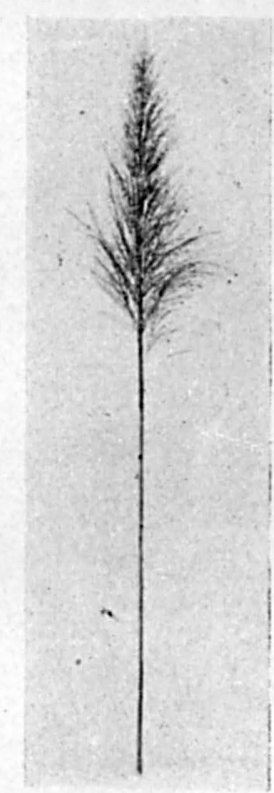

Fig. 6 - Inflorescência da variedade Co. 312 (Original)

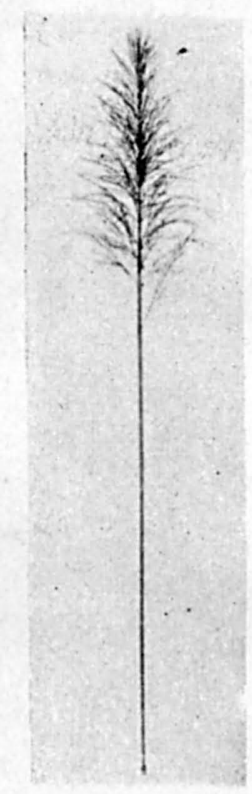

Fig. 5 - Inflorescência da variedade F 29-7 (Original) 
sacarose, diminuindo a quantidade de açúcar aproveitável corno ainda tornando extremamente difícil a fabricaçáo do açúcar. Em nenhum caso obtivemos resultadcs tzo marcantes, trabalhando com 20 variedades diferentes de cana, embora nada possamos afirmar categoricamente, pois nossas observaçðes dạtam de um ano apenas de pesquisas. Comumente encontramos resultados completamente opostos - enriquecimento dà cana, maior pureza do caldo e grande supremacia em açúcar provável nas canas florescidas.

Ai estāo resumidamente condensados os principais porquês que servem para o usineiro e o agricultor prático acharem no florescimento da cana um grande mal.

Nåo obstante, conforme ponderámos estribados nos nossos ulados, o florescimento parece năo causal prejuizo imediato e i) itido nem mesmo na reduçáo da tonelagem por área devido à paralisaçăo do crescimento e no volume do caldo, como afirma a maioria dos autores. O que parece patente é que a variedade tem uma marcante influencia nesse caso.

Os colmos que florescem numa touceira săo por via de regra os mais velhos, os mais grossos, mais desenvolvidos, mais pesados, menos atacados pela broca e us mais ricos de caldo, motivos pelos quais muitas vezes enconiramos maior tonelagem, maior volume de caldo e caldo mais puro nas canas florescidas, principalmente nas canas Coimbatore examinadas. Em alguns casos o açúcar apróveltável é quase $0,5 \%$ a mais nas canas florescidas. A pureza do caldo só muito mais tarde é que comecca a cair.

Outros autores, como EARLE, LABARTHE, etc., têm obtido resultados diferentes em outras regióes, rnas nžo consideramos istes resultados senáo como orientaçăo, uma vez que a nossa upiniāo é que o assunto deve ser atacado e resolvido separadamente, para cada regiăo açucareira.

Em 1933, MEYER obteve os seguintes resultados no municipio de Plracicaba com a POJ 2725, 1.a soca, com 14 meses de idade:

\begin{tabular}{|c|c|c|}
\hline & $\begin{array}{l}\text { Logo após o } \\
\text { florescimento }\end{array}$ & $\begin{array}{l}\text { Depois de } 1 \text { més } \\
\text { de florescidas }\end{array}$ \\
\hline Brix & $\ldots \ldots \ldots \ldots 18,43$ & 13,84 \\
\hline Pol & 15,92 & 9,08 \\
\hline Redutores & 0,52 & 2,63 \\
\hline Pureza & . 86,20 & 65,50 \\
\hline
\end{tabular}

Dste ano nåo obtivemos dentre as milhares de canas examinadas, analisando canas năo com 1 mes depols de floresci- 
Anais da E. S. A. eluiz te Queirois

das, mas mesmo depois de vários meses após a emersåo completa da inflorescéncia e náo encontrámos sequer um dado semelhante a este obtido por MEYER, em que se patenteia de maneira insofismável o desastre produzido pelo florescimento na POJ 2725. Aliás, como já dissemos, esta variedade é a que se torna passada mais ràpldamente depois de florescida que outra qualquer, pois o florescimento nela marca a sua maturaçăo.

Na usina a moagem e o trabalho de fabricação com canas florescidas n̋̌o apresenta nenhuma ancrmalidade para a qual se possa responsabilizar este fenomeno natural da planta.

Dentre os fatores que influem ou governam o florescimento da cana de açúcar podem ser postos em relevo os seguintes:

1 - variedade da cana;

2 - idade da cultura;

3 - sanidade da cultura;

4 - umidade do solo;

5 - natureza do solo;

6 - tratos culturais;

7 - adubaçă

3 - altitude;

9 - época do plantio;

10 - temperatura ambiente.

O florescimento é, pode-se dizer, uma qualidade inerente a variedade, a qual varia estreitamente segundo as condiçoes em que vegeta, aumentando ou diminuindo essa faculdade.

Os fatores externos que determinam o florescimento da cana sendo em tro grande numero e muitos deles de dificil controle prático e, ademais, năo sendo os mesmos para todas as variedades de cana, tornam o estudo do florescimento da cana um problema bastante árido e de dificil soluçăo.

\section{Variedade da cana}

- As variedades de cana apresentam náo só uma capacidade de florescimento muito diferente, cono diferem também no tempo de florescimento. $O$ hábito de florescer é, pois, um caráter auxiliar de certa importancia na classificaçáo das variedades.

Algumas variedades săo por natureza mais propensas ao florescimento do que outras. 0 caso d\& POJ 2725, da CP 27-139, ctos "seedlings" do I. A. C., que florescem todos os anos numa 


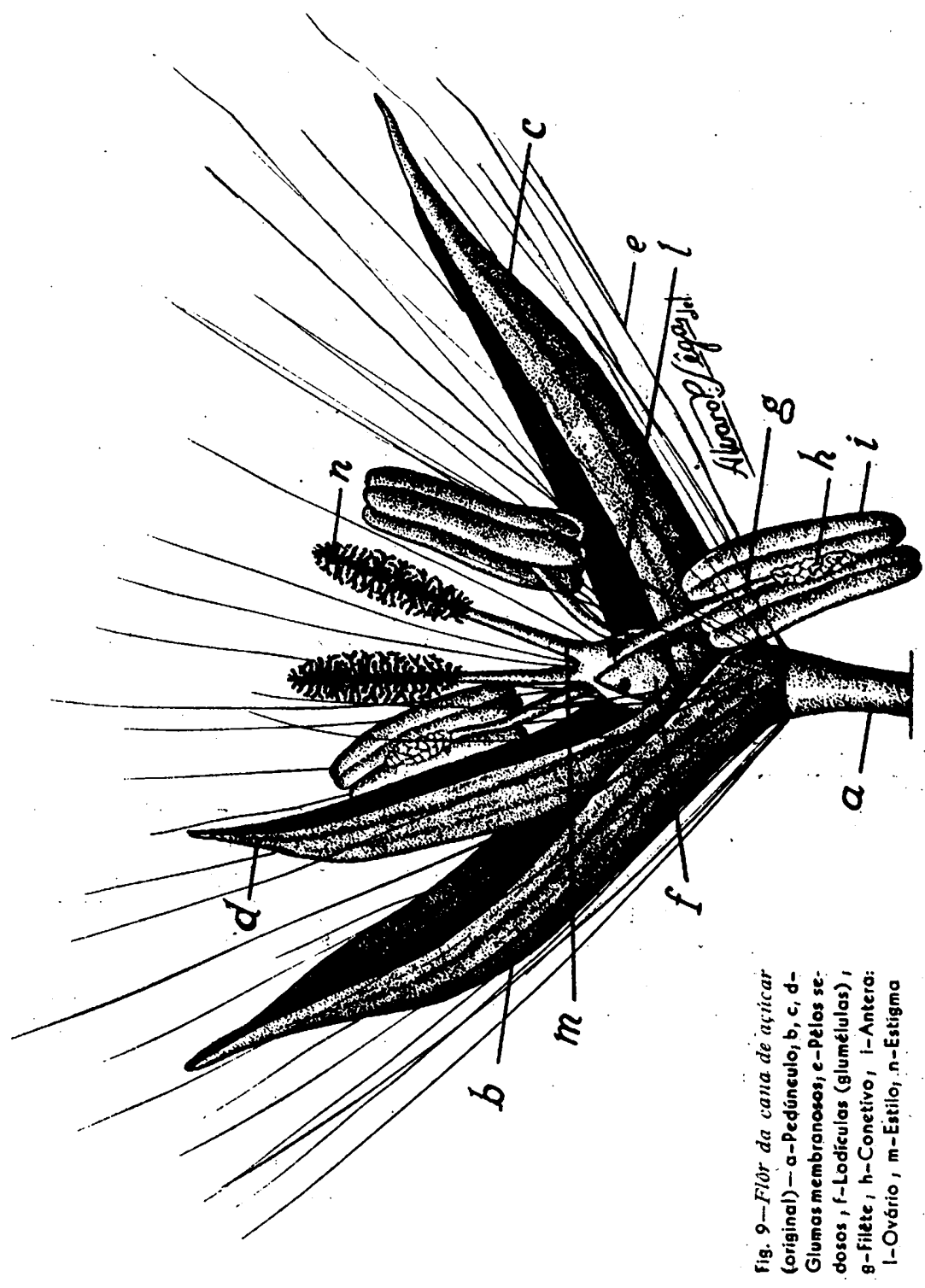


intensidade de $100 \%$ dificultando até a obtenção de boas mudas para renovação de talhóes e de pontas para o enfeixamento das canas cortadas. Ao contrário, a Co. 281, a Co. 290, a POJ 213 e outras raramente florescem, enquanto que outras, como a Taquara, pràticamente nunca florescem.

As diferentes variedades de cana mostrám grande diversidade no grau de desenvolvimento da flor. assim que se coinecem todos os estágios desde as que nunca floresceram até is que produzem flores férteis anualmente.

Certas variedades de cana năo florescem nunca ou apenas fazem a primeira preparação para florescerem; outras produzem uma inflorescência mal formada com poucas flores sempre estéreis; outras ainda, dăo uma iıflorescência bem plumosa mas tornam-se estéris completamente ou parcialmente, isto é, ora é estéril a flộr feminina, ora é a masculina; outras, dando flôres férteis produzem vários "seedlings", os quaís são de peqúena vitalidade $\mathrm{e}$, depols de um breve periodo de desenvolvimento, morrem aos milhares; muitas, por fim, florescem abundantemente dando flores férteis que produzem "seedlings" vigorosos que podem ter um crescimento garantido até a maturạça.

devido a esta disparidade que se nota na massa de flores produzidas pelas canas em um dado ano grandes diferenças, 0 que constitui um fato de grande importáncia para o estudo de cruzamentos, pois para a produção de novos "seedlings" é preciso abundância de flores férteis, que se contam pela maior ou menor proporção de anteras abertas.

A inflorescéncia da cana de açúcar é uma panícula ampla, piramidal, cuja ráquis (eixo principal) se constitui do prolongamento do último internódio do colmo; dela partem, com disrosição pràticamente verticilada, numercsos eixos secundários, que se desdobram, por sua vez, em eixos terciários e compostos de segmentos articulados. Sobbre as ramificações terciárias inserem-se as espiguetas (inflorescências elementares), uniflo1as, hermafroditas, dispostas aos pares, sendo uma séssil e cutra pedicelada. Distribuidos ao redor das bases das espiguelas, das articulaçóes das ramificaçóes secundárias e terciárias, ixistem abundantes e longos pêlos sedosos.

As espiguetas são envolvidas por três glumas membranáceas, de inserção dística, sendo a exterior mais consistente que as outras; na base da flor e coberta pela terceira gluma, inscrese a única glumela, hialina, cuja forma e tamanho variam com a variedade de cana. Em seguida vêm as duas glumélulas (10dículas), que por entumecéncia, em época apropriada, produ- 


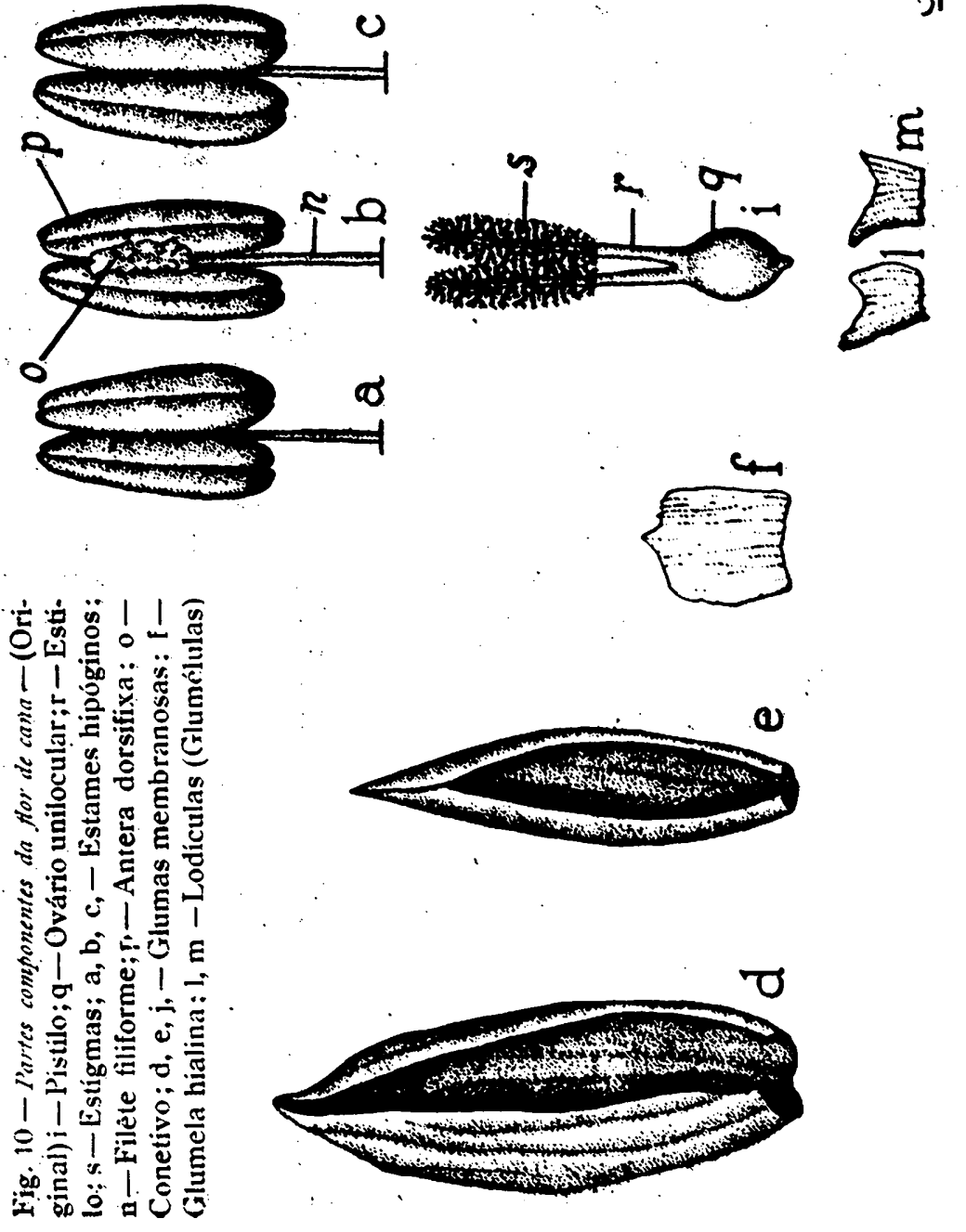


zem a antese (abertura da fior). O androceu é constituido de tres estames hipóginos, de filetes filiformes e delicados; anteras lineares e fixadas pelo dorso (dorsifixas). O pistilo comprese de um ovário unilocular, encerrando apenas um óvulo (rudimento seminal), de dois estilos, terminados por estigmas plumosos e de coloraçá roxa-avermelhada.

A diferença na forma da inflorescencia e da fertilidade das flóres pode servir como caráter auxillar de classificaçăo das variedades. Assim, a forma dos eixos secundários varia nas diferentes variedades, como também a coloraçăo que $e$, de um modo geral, avermelhada nas canas escuras ou coloridas. Fazem exceçáo a Co. 290 e a Co. 426, que săo bem mais claras que o colmo, e a Co. 223, cuja cór se aproxima da do colmo.

Os pares de espiguetas săo alternados, mas em certos casos aparecem 2 pares em cada nó, como na Co. 285, Co. 313 e Co. 437. Fm certas variedades a flor séssil é a que se abre primeiro e a penduculada no dia seguinte; noutras dá-se o contrário, enquanto que num terceiro grupo como o da Co. 357 se verificam os dois casos, simultaneamente na mesma inflorescencia.

As fotografias anexas, originais dos a atores, servem para dar uma pálida idéla da conformaçác das inflorescencias de diversas variedades estudadas por eles.

Mesmo quando a cana floresce normalmente é preciso que as condiçóes de calor e umidade sejam suficientes para que se liè a maturaçáo das sementes. essa, possivelmente, a rąăo pela qual, em certas regibes do Estadu de Săo Paulo, onde a precipitaçăo aquosa é pequena, muitas variedades de cana que florescem năo dăo sementes férteis, ao contrário do que se verifica comumente no litoral deste Estado.

Dentro dos limites regionais, as diferentes variedades têm um tempo próprio de florescimento. Mas, mesmo assim, obseryamos frequentemente que as canas grossas florescem primeiro e mais faclimente do que as canas finas e que as marginais numa touceira emitem o escapo floral primeiro que as do centro. Quando as canas finas de uma touceira começam a florescer, a maior parte das canas gossas já floresceram e estáo secando. Isso, independentemente da variedade e da influencia das condiçóes locais. Hsse fato é de grande alcance nos trabalhos de cruzamento.

\section{Idade da cultura}

H possivel que a idade da cultura tenha certa influência na trequéncia do florescimento, porém ainda é cedo para afir- 


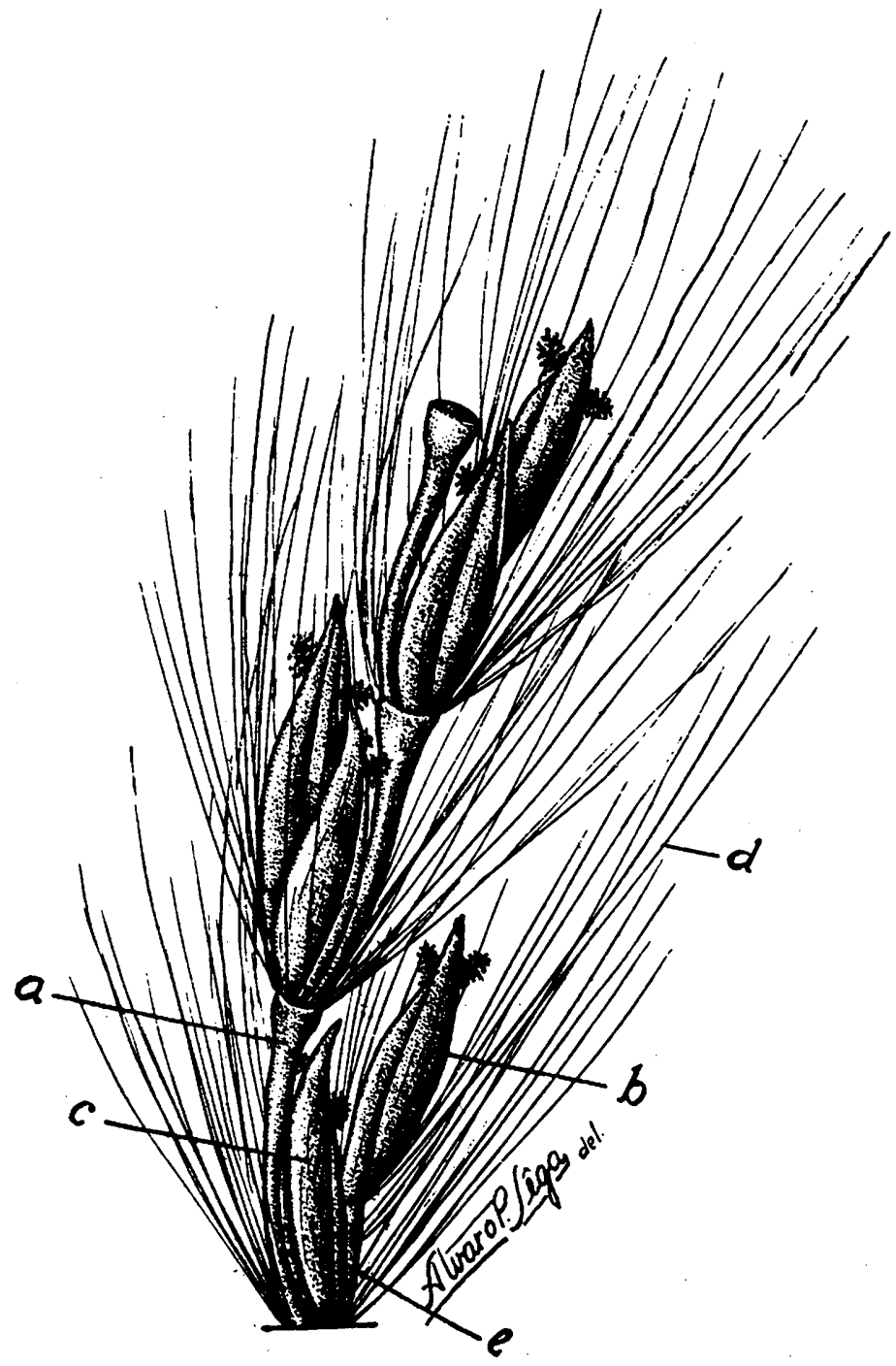

Fig. 11 -- Espiguetas inseridas sôbre o eixo terciário (Original)

a) - Segmento articulado do eixo terciário; b) - Flor pedicelauni; c) -Flor séssil; dl - Pêlos; el - Pedúnculo. 
marmos êsse fato. Parece que a cana planta ou de 1.0 corte apresenta menor frequéncia ao florescimento que a soqueira. 0 professor JAYME ROCHA DE ALMEIDA, fazendo observaçס́es neste sentido na variedade CP 27-139, oteve os seguintes resultados:

Cana planta ................4 a $6 \%$

Soqueira $\ldots \ldots \ldots \ldots \ldots \ldots \ldots \ldots \ldots$ a $10 \%$.

Quanto à idade da cana, que depende naturalmente da data do plantio ou do corte, aquêle professor já conseguiu catalogar os resultados abaixo, em anos anteriores:

Canas com 5 meses ........ $0 \%$ de florescimento;

Canas com 10 meses ........12\% de florescimento;

Canas com 15 meses ........ 15\% de florescimento.

Entretanto é cedo ainda para se tirar uma conclusão a respeito, dado o pequeno número de observaçőes feitas neste sentido. Além disso há a possibilidade das observações serem mascaradas pela interferéncia de outros fatores, porquanto o tempo de florescimento varia muito de acordo com a data em que se fez o corte. Se êste fór bem regulado talvez seja pussível evitar, pelo menos em parte, o florescimento.

t preciso não se esquecer que o problema do contrôle dêsse hábito da cana florescer é muito diferente nas regiōes onde as canas amadurecem tardiamente ou precocemente. Quando a cana floresce próximo ou no periodo de maturação o florescimento causa prejuizo palpável nas variedades que passam com rapidez. Já nảo acontece o mesmo se o florescimento se der antes da cana estar vizinha da maturação, pois neste caso há possibilidade de um enriquecimento.

\section{Sanidade da cultura}

Quando a cana é intensamente atacada por um mal grave como o mosaico ou a broca, os quais impedem o seu desenvolvimento normal, acredita a maioria dos autores, ela parece se predispor ao florescimento como um meio de defesa natural para a perpetuação da espécie.

Tudo que afirmássemos agora sôłore êste delicado assunto seria uma ousadia nossa, diante do que nos fol dado observar no primeiro ano das nossas investigaçóes. Entretanto, é preciso que se diga que desde o momento em que começámos os nossos 
(nsaios analiticos, o que ficava bem patente ao fichar as milhares de canas, em pé, de cada talhăo, era o estado mais raquítico de certas canas que permaneceram sem florescer até que se concluiram as nossas pesquisas de 1944. Nâo houve, pols, uma predisposiçáo destas canas mal desenvolvidas, atacadas de brocas e outros males para a perpetuaçáo da espécie. Pelo conirário, por serem dessa conformaçăo anormal, de desenvolvimento retardado e muito broqueadas é que năo produziram a inflorescencia, notada só nas canas normais, vigorosas e mais sadias.

A maioria dos autores que estudou o florescimento da cana atribui o maior ataque da broca nas canas florescidas ao fato de serem elas mais moles; ainda mais, admicem outros, que as canas que brotam mais intensamente năo săo tăo moles como as que têm menor tendencia à brotaçác.

Nossas observaçōes, se bem que muito incompletas ainda, Iáo estăo de acơrdo com êsse modo de ver. Pelo contrário, am muitos casos elas nos transportaram para um campo diametralmente oposto.

De fato, observando a intensidade do ataque da broca nas canas năo florescidas e nas florescidas notámos que as primeiras săo, por via de regra, mais atacadas que estas provàvelmenie devido à menor \% de fibra que encerram e que lhes dá 0 caráter de menor dureza. Independentemence do florescimento as variedades sáo por natureza, umas mais moles que outras devido ao seu conteúdo de fibra.

Resta apurar convenientemente, nos ensaios futuros, se é a broca que coopera para acelerar o florescimento de uma variedade; se é devido ao maior ataque de broca que o colmo não floresce ou se é o fato de ter menos fibra que torna a variedade mais suscetivel ao ataque da broca.

Além disso, a variedade CP 29-137 que acusou a mais alta tendéncia à brotação lateral, pois de milhares de colmos florescidos, fichados e examinados, năo encontrámos um sequer sem 1 ou mais brotos, é muito mais mole por ser muito mais pobre d: fibra que as variedades Co.285, Co.312, Tuc. 519 e uuuras, que apenas chegaram a entumecer as gemas superiores mostrando ligeiro sinal de brotaçăo.

A POJ 2878, que também. é muito menos rica de fibra que a Tuc. 519, brota intensamente, produzindo rebentőes que aproveitados na moagem causam sérios distúrbios na fabricação, na seçáo correspondente à clarificação do caldo. bem vercade que aqui se trata de brotos normais e nåo de brotos la- 
terais, aéreos, superiores como é comum da POJ 2727, tanto na cana florescida como na cana năo florescida.

Permanece, portanto, a dúvida - haverá relação entre a riqueza em fibras de uma variedade e a sua tendência à brotaçăo?

\section{Umidade do solo}

O contróle exato désse fator é extremamente difícil, senãn impossivel, por năo ser suscetível de ser julgado em separado.

De fato, observando-se o que se passa pelo mundo, nota-se que exu certos lugares a chuva abundante durante o crescimento da cana favorece o seu florescimento. Os talhóes que são alagados por enchentes periódicas são os primeiros a florescerem no canavial. Nas lavouras irrigadas o florescimento é máximn, como também florescem mais intensamente as canas marginais dos talhões que se estendem ao longo dos cursos dágua, comparativamente às do centro do talháo. Nessas regiós durante os anos chuvosos, a cana floresce abundantemente, enquanto que depois de periodos de séca prolongados, praticamente a cana năo floresce.

Diante dêstes resultados só poderemos conduzir nosso pensamento para essa conclusăo : - maior umidade do solo coopera diretamente para maior florescimento da cana.

Mudemos, entretanto, de cenário.

Noutras regióes iremos encontrar o reverso da medalha. Quanto mais séco fôr o solo mais predisuosta a cana se torna a florescer, porque êste $\epsilon$ stado impede o seu desenvolvimento normal, paralisando mais cedo o ciclo vegetativo. esse estado de coisas nûs foi dado observar várias vezes em Piracicaba, 0 maior centro açucareiro do Estado de Săo Paulo.

Af temos duas opinioes certas, observadas por experimentadores vários em diferentes partes das regioes açucareiras do mundo, as quais, por serem opostas, se tornam, consequentemente, dificeis de serem conciliadas.

Em que ficamos, pois ?

A maneira mais correta de avaliar álé que ponto o fator umidade do solo interfere no florescimento, é admitir que a intensidade da precipitação anual e a sua distribuição é que têm marcada e direta influência no floreścimento. A interforência durante o perfodo mais ativo do crescimento normal da cana, de uma interrupçáo brusca de umidade ou de sêca tem efeito favorável ao florescimento.

Em São Paulo, a cana de açúcar, por via de regra, entra em 
vias de maturação em Maio. Se houver umidade e temperatura favoráveis até Abril, a atividade vegetativa determina um crescimento e um desenvolvimento normais à cana de açúcar. Caindo agora a temperatura, como acontece geralmente em são Paulo, e havendo daí por diante chuvas periódicas para suprir as necessidades da planta, o florescimento comumente é pequeno ou práticamente nulo. Mas se as chuvas paralisarem bruscamente em fins de Abril e continuar.alta a temperatura, a. harmonia necessária entre os fatores umidade e temperatura fica iterrompida e o florescimento é abundante.

Conforme o gráfico que apresentamios, verifica-se que o ano de 1944 foi multo irregular em sáo Paulo, contrariando o desenvolvimento normal da cana e causando visíveis dificuldades no trabalho das usinas.

Entretanto, não há ainda uma prova cabal para mostrar porque sob condiçбes favoráveis de nutriçāo e de umidade a cana floresce, enquanto que em circunstáncias adversas ela não floresce, sendo a reciproca também verdadeira.

$\mathrm{Da}$ fato, as causas que determinam a formação das flóres na cana de açúcar são ainda pouco conhecidas. Tanto $\rho$ crescimento como a formação das flores se dão sob a influência dos mesmos fatores ambientes (luz, calor, umidade, etc.), porém, como vimos acima, é a desarmonia ou a variação quantitativa dêsses fatores que ocasiona ora a predomináncia de um ora a de outro fenómeno.

E possível que a variação quantitativa dêsses fatores determine uma desproporçáo ou desiquilíbrio entre a quantidade de matéria orgánica elaborada nas fólhas à custa da síntese clorofiliana e acumulada no colmo, e a seiva bruta (dgua e sais minerais) absorvida pelas raizes da cana.

Expliquemo-nos com mais clareza.

Quando a síntese clorofiliana é intensa, porém, há predominio de seiva bruta, a cana tende a crescer, pois os sais minerais :m solução contribuem para êsse fellómeno antagónico ao do florescimento. to que se dá em Săo Paulo, quando depois de Abril, a temperatura diminui mas as chuvas não são completa.mente paralisadas. Note-se pelo gráfico da página seguinte que, embora a temperatura tenha diminuido depois de Abril, as chuvas foram praticamente. nulas.

Se, agora, a sintese clorofiliana é intensa, e por falta de umidade a absorçáo da solução salina é peqaena, predominarã a matéria orgânica, cuja presença parece ser o fator responsável pelo florescimento, tendendo a cana a emitir o escapo flcral. Isso se verifica quando, atingindo a cana em Abril intensa ati- 
vidade vegetativa, paralizam-se bruscamente as chuvas $€$ a iemperatura se mantém elevada. Também não foi o que se deu cm São Paulo em 1944, conforme se depreende do exame do gráfico mostrado adiante.

Havendo um certo equilíbrio médio entre a absorção de água e sais nutritivos pelas raizes e a formação de matéria orgànica elaborada pelas fólhas, a produçăo de flor ou o crescimento vegetativo fica condicionado à intensidade da iluminação. Se a temperatura se mantiver elevada e permanente, o cneficiente respiratorio aumenta, o gasto dos hidratos de carbono se eleva, predominam os sais nutritịos e o florescimento é rrejudicadu. Porém, se a temperatura cair e a assimilação continuur no mesmo rítmo devido a intensidade da iluminaçăo, verificarse-á logo o predominio de matéria orgânica sóbre a seiva bruta e a cana floresce.

interessante anotar aqui as observações feitas na India pelos autores BATHAM e NIGAN, ségundo os quais exist: urna correlação negativa entre a área das fôlhas e o pêso do caldo obtido dos respectivos colmos conforme se verifica dos números abaixo :

$\begin{array}{ccc}\text { Variedades de cana } & \text { Area d s folhas em cms.2 } & \text { o/0 média do pêso de caldo } \\ \text { Co. } 377 & 3316 & 54,4 \\ \text { Co. } 395 & 3056 & 55,9 \\ \text { Co. } 205 & 2283 & 56,8 \\ \text { Co. } 313 & 2739 & 57, i \\ \text { Co. } 393 & 2490 & 57,9 \\ \text { Co. } 210 & 2286 & 57,2 \\ \text { Co. } 310 & 2055 & 59,8 \\ \text { Co. } 213 & 2615 & 59,6 \\ \text { Co. } 387 & 2074 & 63,4 \\ \text { Co. } 351 & 2462 & 63,2 \\ \text { Co. } 290 & 2414 & 63,8 \\ \text { Co. } 312 & 1962 & 64,7 \\ \text { Co. } 353 & 1775 & 68,2\end{array}$

bom frisar, no entanto, que trabalhos já feitos mostram que a intensidade da iluminação não é de influência dominante. no florescimento da cana, embora uma diminuição no temdo de exposição à luz favoreça uma condição mais ativa de vegetação.

Assim se procura explicar hoje porque a interferência de uma interrupção brusca de umidade ou de sêca durante o pelíodo mais ativo de crescimento da cana favorece o florescimento da cana de açúcar. 

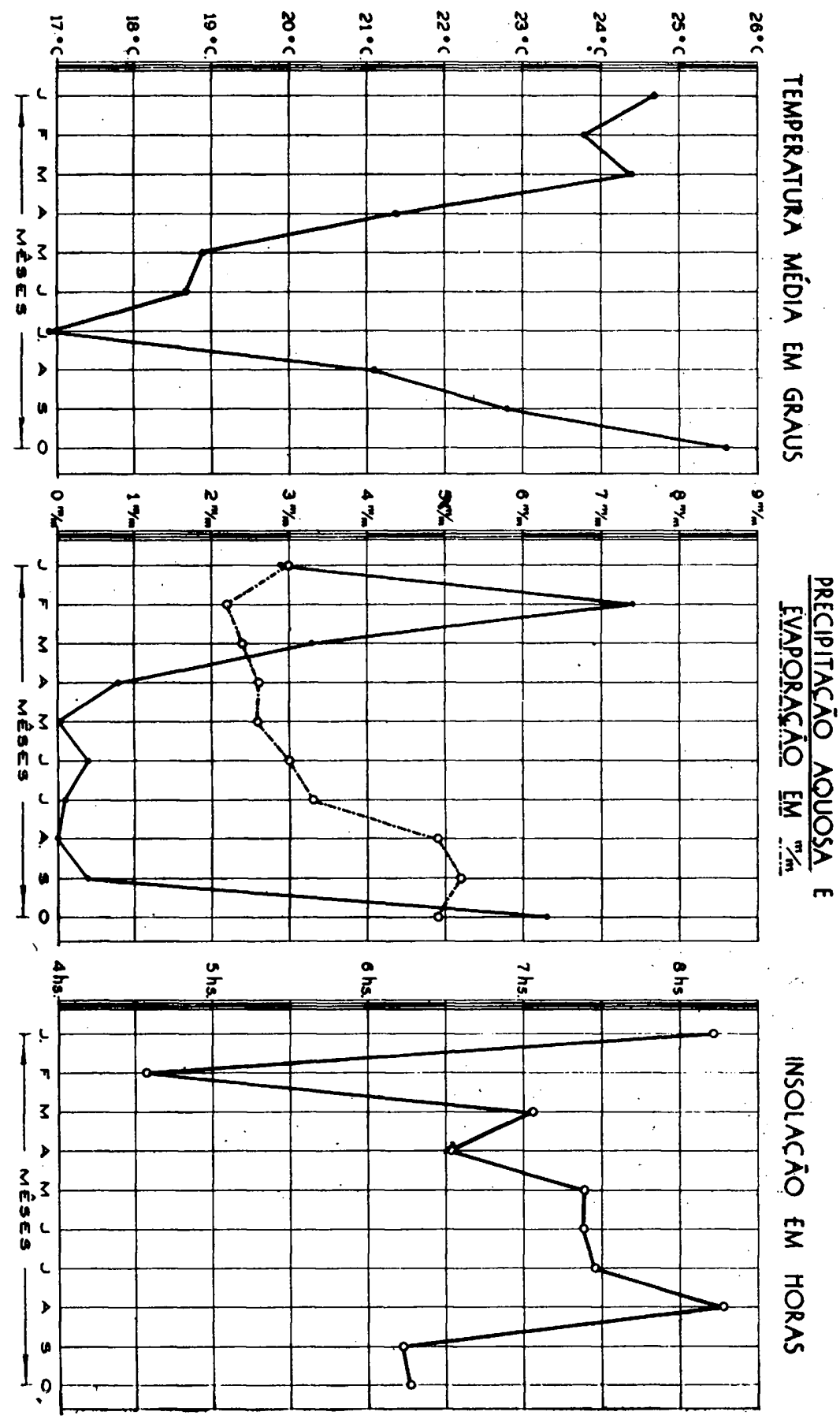
Autores há que consideram o desequilibrio entre a quantidade de água absorvida pelas raizes e a evaporada pelas folhas, como a causa do florescimento prematuro da cana. Este se dá sempre que predominar a primeira condiçăo. A se admitir esta explicaçăo de LABARTHE, pela irrigaçăo pode-se controlar - florescimento da cana. Quando esta absorve muita água precipita o florescimento, porém se a absorção é pequena a cana tenderá a crescer e novas fôlhas aparteerăo.

O sistema radicular da planta, que é dependente da variedade e do coráter do solo, passa então a ter uma importáncia enorme no florescimento.

Que os fatores climatéricos têm influência no florescimento é coisa fora de dúvida. Resta saber é como interpretar a sua açăo $€$ até quando essa influência se manifesta.

A seguinte observação "de MEYER em Piracicaba é um exemplo frizante da ação climática, reprodução dos mesmos fatos já constatados em outras regióes. A variedade POJ 2725 em 4 anos consecutivos de observação, em terra roxa, de relativa fertilidade, não recebendo outros tratos culturais que não fóssem os comumente prestados aos canaviais em cultura extensiva, acusou a seguinte intensidade de florescimento:

Cana planta - năo floresceu;

Soqueira de 1.0 corte - floresceu $100 \%$;

Soqueira de 2.0 corte - floresceu muito pouco;

Soqueira de 3.0 corte - floresceu $100 \%$.

\section{Natureza e caráter do solo}

A natureza, o caráter, a fertilidade e o trabalho do solo influem também sôbre a variação do grau de florescimento das diferentes variedades de cana, se bem que até hoje a extensão dessa influência não fol determinada com precisão.

Sabe-se que a maturação da cana se dá mais fàcilmente em solos pobres de elementos nutritivos, porosos e sêcos, onde há sempre maior circulaçăo de ar do que nos solos ricos, compacto:s e úmidos. Será que essas mesmas caussas que cooperam para apressar a maturaçăo das canas favorecem também o florescimento? Resta saber com certeza.

\section{'Iratos culturais}

Quando se faz uma aração rasa rente às touceiras, de tal 
modo que parte das raizes sejam cortadas, êsse tratamento cultural predispoe a cana a florescer porque impede o seu desenvolvimento normal, ou porque, reduzindo-se o sistema radicuiar da cana, dimiui-se a quantidade de soluçăo salina absorvida pelas raizes e dá-se um aumento relativo da matéria orgárica, responsável pelo estabelecimento das formaçōes florais. Dal o cuidado que se deve ter no tratamento das soqueiras.

Antigamente costumava-se, em certas regibes, cortar a cana ainda muito nova para forçá-la a produzir ,novos brotos, que floresciam por ultimo. Tal prática foi abandonada em virtude dos resultados negativos obtidos.

Neste caso aumenta-se a capacidade absortiva de sais minerais e água (seiva bruta) pelas raizes, em detrimento da quancidade de matéria orgánica elaborada pelas folhas.

\section{Adubação}

A classe de adubos empregada parece ter influencia no florescimento. Assim, o nitrogénio mineral ou orgánico assiinilável pela cana tem decidido efeito em reduzir e muitas vezes em prevenir completamente 0 florescimento se aplicado em tempo certo e de preferéncia com irrigaçáo suficiente.

O Salitre do Chile e o sulfato de amónio aplicados a um intervalo de 20 a 30 dias antes do período de florescimento prolongam a atividade vegetativa retardando ou impedindo o florescimento.

Com o sulfato de amónio já se verificou que na dose de 1 tonelada por alqueire. causa apenas $11 \%$ de florescimento; aplicado na dose de $\mathbf{5 0 0}$ quilos a intensidade de flarescimento 1oi de $54 \%$ e onde náo se aplicou o sulfato de amónio a \% de ilorescimento subiu a $72 \%$.

Os adubos fosfatados e potássicos agem. de modo contrárjo, favorecendo o florescimento, se bem que essa açăo, que é mais cvidente para os adubos fosfatados, nem sempre se verilica na prática.

\section{Altitude e latitude}

A altitude e a latitude tem uma influencia decidida no florescimento devido às mudanças que elas causam nas condiçōes climáticas (umidade, calor, luz, ventos, etc.).

Ein certas regibes da India tem-se constatado que mesmo yara a mesma variedade de cana, há pouco ou nenhum florescimento a 15 metros abaixo do nivel, do mar; cresce esta 
tendência acentuadamente até 150 metros acima do nivel do mar; daf por diante uma queda ocorre na intensidade do florescimento até 300 metros, acima da qual poucas canas florescem. Idêntica influência se observa em Hawaii.

No Brasil parece-nos que ainda ninguem estudou 0 assunto, mas o que é bem verdade é que entre nós a altitude parece não ter aquela influência no florescimento, pois êste, se dá abundantemente na quota 0 (Santos), a 700 metros acima do nivel do mar (Pirácicaba), como em Franca, a 1.033 metros de altitude.

Ein relação à época do plantio, veja-se o que se disse sóbre a idade da cultura; sôbre a temperatura ambiente, leiase a influência da umidade do solo.

\section{Análise estatística}

Com o fim exclusivo de verificar o contraste entre a com. posiçãu das canas florescidas e não florescidas procedemos a uma análise estatística dos dados analiticos obtidos. Por se iratar de um ensaio preliminar, utilizámos o método comum, que será ilustrado a seguir. Assim procedemos porque nos pareceu desnecessário o emprégo de um método muito rigoroso de análise estatística, mesmo porque os dados analíticos obtidos êste ano não o permitiam.

Entretanto, a título de confirmação, utilizámos também um método mais rigoroso indicado por FISHER.

Eın relação à variedade $F$ 29-7 chegámos aos seguintes resultados:

\section{ANALISE DO BRIX}

A - Em primeiro lugar extraimos a média $(\bar{v})$ do Brix cio calco das canas florescidas usando a seguinte fórmula:

$$
\overline{\mathrm{v}}=\frac{\stackrel{P}{\mathrm{v}}}{\mathrm{n}}
$$

na qual,

$$
\begin{aligned}
\mathrm{v} & =\mathrm{a} \text { média procurada; } \\
\mathrm{v}_{\mathrm{v}} & =\mathrm{a} \text { soma dos valores acharlos } \\
\mathrm{n} & =\mathrm{a} \text { número dêsses valores. }
\end{aligned}
$$




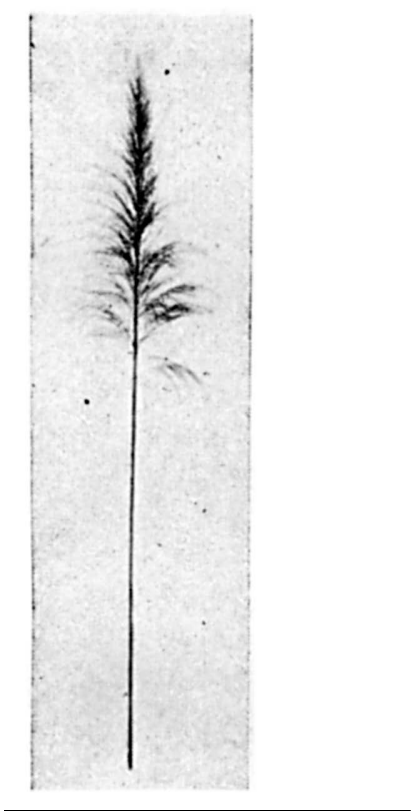

Fig. 7 - Inflorescência da variedade Co. 285 (Original)

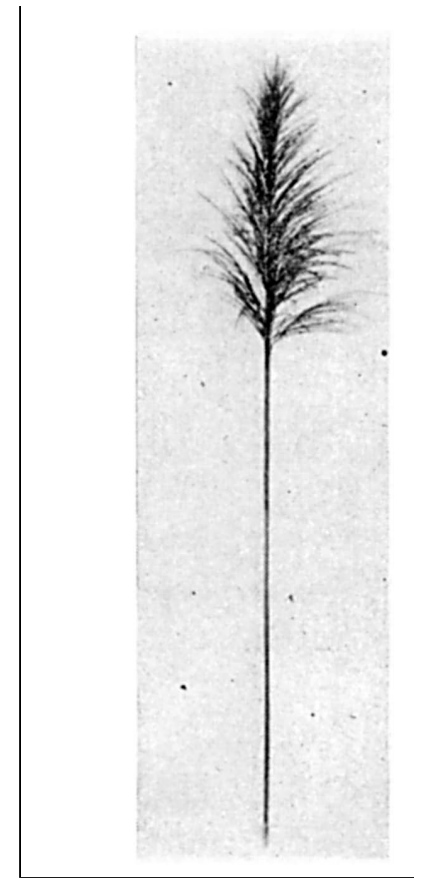

Fig. 8 - Inflorescência da variedade P 33-29

(Original) 

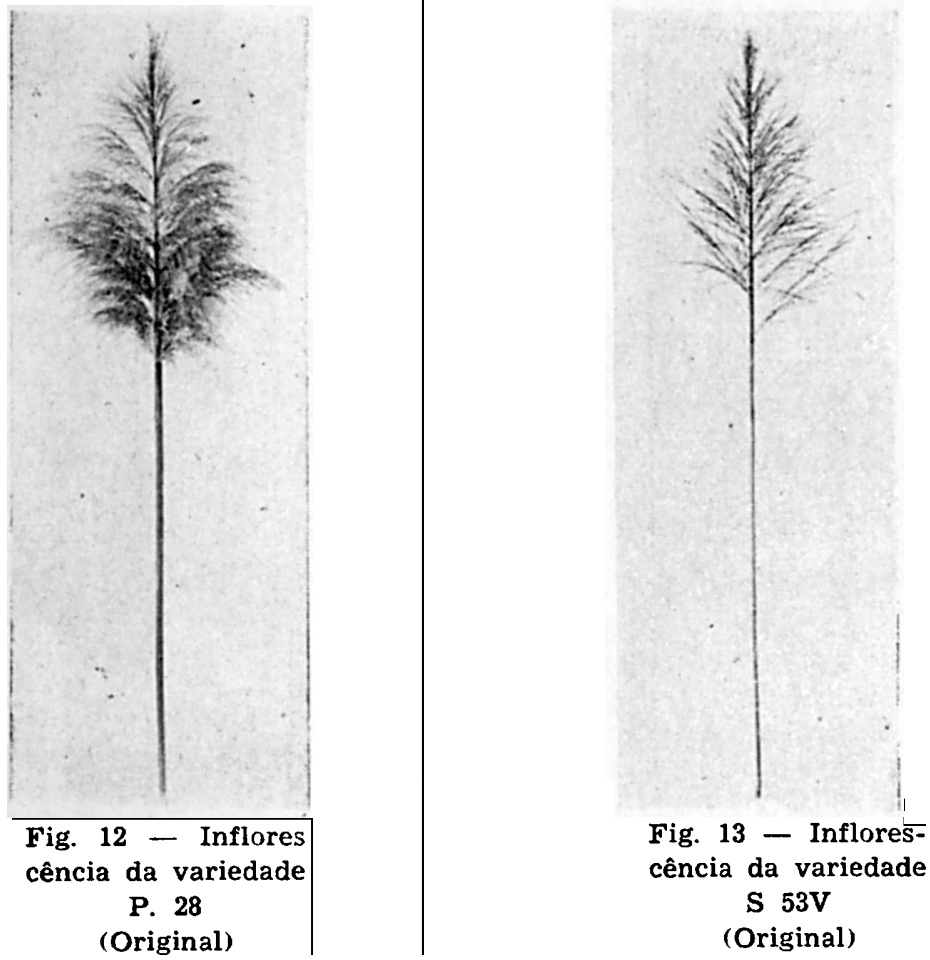


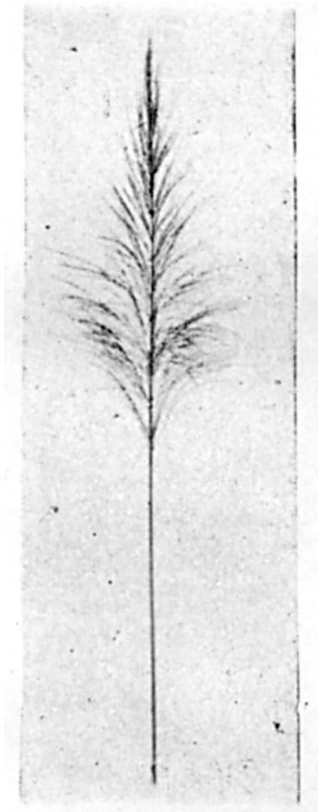

Fig. 14 - Inflorescência da variedade Kassoer Listada (Original)

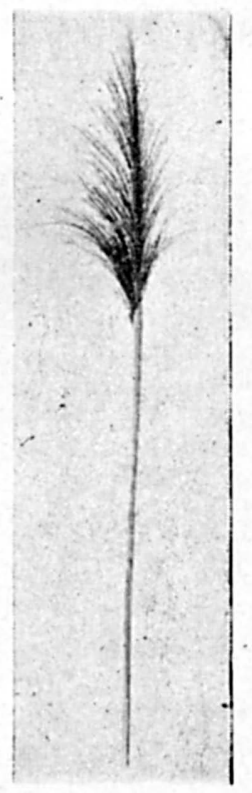

Fig. 15 - Inflorescência da variedade Kassoer (Originai) 
Obtivemos o seguinte resultado:

$$
\bar{v}=\frac{1 v}{n}=\frac{1.372,75}{68}=20,187
$$

O erro standard da média fol achado pela fórmula:

$$
n v= \pm \sqrt{\frac{2 v^{2}-(\bar{n})^{2}}{n(n-1)}}
$$

unde,

$\sigma \mathrm{v}=o$ érro standard da média;

' $v^{2}=$ a soma dos quadrados dos valores em anúlisr, conservando os demais caracteres a mesma significação da fórmula anterior.

A aplicaçáo da fórmula nos deu o seguinte êrro standard do Brix do caldo das canas florescidas:

$$
\sigma \bar{v}= \pm \sqrt{\frac{27.803,42-\frac{(1.372,75)^{2}}{68}}{68.67} \frac{68}{0,14165}}= \pm 0
$$

Nos cálculos dos quadrados fol de valor inestimável para riós a tabela de TIMPENFELD.

Para as canas não florescidas as mesmas fórmulas nos deram os. seguintes resultados:

$$
\begin{gathered}
\bar{v}_{1}=\frac{1.383,88}{68}=20,352 \\
\sigma \bar{v}_{1}= \pm \sqrt{\frac{\sqrt{28.216,35-\frac{(1.383,88)^{2}}{68}}}{68.67}}= \pm 0,107455
\end{gathered}
$$


Em seguida achámos o êrro standard da diferença das médias pela fórmula:

$$
\text { " dif }= \pm \sqrt{\sigma_{\bar{v}}^{2}+\sigma_{\bar{v}_{1}}^{2}}
$$

Portanto:

$$
\sigma \text { iif }= \pm \sqrt{(0,14165)^{2}+(0,10745)^{2}}= \pm 0,17779
$$

lizemos então o D-test :

$$
\begin{aligned}
& \delta=\frac{20,187-20,352}{0,17779}=-0,9281 \\
& \mathrm{~g}=67+67=134
\end{aligned}
$$

sendo g o grau de liberdade.

Comparando-se o valor achado $(0,9281)$ com os limites habituais de $5 \%$ de probabilidades $(1,96)$ e $1 \%$ de probabilidades $(2,58)$, verifica-se logo que o resultado é insignificante e, portanto, que não há diferença estatistica significativa entre o Brix do caldo das canas florescidas e o Brix do caldo das canas não florescidas da variedade F 29-7.

B - A título de confirmação fizemos um outro test que é - que se segue, no qual aproveitámos o fato de serem as ca. nas florescidas e não florescidas de cada uma das 68 análises, colhidas no mesmo dia e, tanto quanto possivel, na mesma touceira. Assim o número 19,82 dos dados anexos (Quadro I) refere-se a canas florescidas colhidas no mesmo dia e na mesma couceira, enquanto que as não florescidas nos deram o valor 20,42 que lhe é fronteiro.

Fizemos então a diferença:

Brix das canas florescidas - Brix das canas não florescidas em cada uma das 68 análises. Essas diferenças eram ora + ura - (Quadro I). Foi feita a sua soma algébrica, que deu:

$$
\sum \text { dif }=-11,13 \text {. }
$$


QUADRO I

BRIX DO CALDO EM F-29-7

\begin{tabular}{|c|c|c|c|c|c|c|c|}
\hline 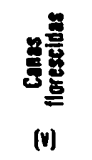 & 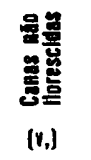 & $\begin{array}{c}\text { 롫 } \\
\text { 兽 } \\
\text { (dili.) }\end{array}$ & 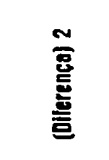 & 总 & 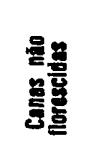 & $\begin{array}{l}\text { 胥 } \\
\text { 言 }\end{array}$ & 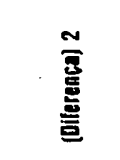 \\
\hline 19,8 & 20,42 & $-0,60$ & 0,3600 & 20,80 & 22,00 & $-1,20$ & 1,4400 \\
\hline & 20,43 & $-1,10$ & 1,2100 & 19,22 & 19,22 & 0,00 & 0,0000 \\
\hline 20,80 & 20,00 & $+0,80$ & 0,6400 & 20,60 & 20,20 & $\begin{array}{r}0,40 \\
\end{array}$ & 0,1600 \\
\hline 19,20 & 21,00 & $-1,80$ & 3,2400 & 20,00 & 19,80 & $\begin{array}{r}+ \\
+0,20\end{array}$ & 0,0400 \\
\hline 21,60 & 20,90 & $\begin{array}{r}0,70 \\
\end{array}$ & 0,4900 & 21,20 & 20,40 & $\begin{array}{r}+0,80 \\
+0\end{array}$ & 0,6400 \\
\hline 21,60 & 19,60 & $+2,00$ & 4,0000 & 20,00 & 21,20 & $-1,20$ & 1,4400 \\
\hline 18,65 & 20,65 & $-2,00$ & 4,0000 & 21,00 & 21,40 & $-0,40$ & 0,1600 \\
\hline 19,43 & 20,22 & $-0,79$ & 0,6241 & 17,55 & 19,55 & $-2,00$ & 4,0000 \\
\hline 20,60 & 19,80 & $\begin{array}{r}+0,80 \\
\end{array}$ & 0,6400 & 20,55 & 19,55 & $\begin{array}{r}1,00 \\
+1,00\end{array}$ & 1,0000 \\
\hline 20,40 & 19,80 & $\begin{array}{r}+0,60 \\
\end{array}$ & 0,3600 & 21,25 & 2 & $\begin{array}{r}0,40 \\
+\quad 0\end{array}$ & 690 \\
\hline 20,80 & 20,40 & $\begin{array}{r}+0,40 \\
+0\end{array}$ & 0,1600 & 21,00 & 1 & $\begin{array}{r}+1,05 \\
+1,05\end{array}$ & 025 \\
\hline 19,90 & 21,10 & $-1,20$ & 1,4 & 20,00 & 19 & $\begin{array}{r}0,40 \\
+\quad 0,40\end{array}$ & 300 \\
\hline 20,50 & 21,10 & $-0,60$ & 0,3 & 19,15 & & $-2,00$ & 00 \\
\hline 20,00 & 20,80 & $-0,80$ & 0,6400 & 21,15 & & $\begin{array}{r}0,80 \\
+0,80\end{array}$ & 400 \\
\hline 20,80 & 20, & 0,00 & 0,0 & 21,60 & & $-0,20$ & 0,0400 \\
\hline 20,80 & 19 & $\begin{array}{r}1,00 \\
+\end{array}$ & 1,0 & 20,80 & & $-0,80$ & 0,6400 \\
\hline 20,45 & 20 , & $-0,50$ & 0,2500 & 15,50 & & -4.00 & 16.0000 \\
\hline 21,15 & 20 & +0.60 & 0,3 & 20.30 & 19 & +0.60 & 600 \\
\hline 20,40 & 20 & 0,00 & 0, & 20,50 & 17 & $\begin{array}{r}3,00 \\
+3,0\end{array}$ & 00 \\
\hline 19,0 & 21, & $-2,40$ & 5,7 & 19.70 & 19 & $-0,20$ & 400 \\
\hline 20,6 & 21 & $-0,60$ & 0, & 20,30 & 19 & $+1,00$ & 1,0000 \\
\hline 21,8 & 20 & $+1,00$ & 1 , & 19,50 & 18 & $\begin{array}{r}0,80 \\
+\quad 0,\end{array}$ & 0,6400 \\
\hline 19 & 19 & $+0,23$ & 0 , & 19,70 & 19 & $\begin{array}{r}0,40 \\
+0\end{array}$ & 0,1600 \\
\hline 20 & 21,20 & $-0,60$ & 0 , & 18,30 & 19 & $-1,00$ & 1,0000 \\
\hline 20 & 20 & $\begin{array}{r}+0,20 \\
\end{array}$ & 0 , & 20,30 & 19 & $+0,80$ & 0,6400 \\
\hline 18 & 21,05 & $-2,65$ & 7,0 & 19,05 & 20 & $-1,65$ & 2,7225 \\
\hline & 20 & $-1,20$ & 1 & 20,45 & 20 & $-0,40$ & 0,1600 \\
\hline 21 & 21,80 & 0,00 & 0,0 & 21,25 & 18 & $\begin{array}{r}2,60 \\
\end{array}$ & 6,7600 \\
\hline 20 & 20 & $+0,21$ & 0,0 & 19,90 & & $\begin{array}{r}0,60 \\
+\quad 0,60\end{array}$ & 0,3600 \\
\hline 21 & 20 , & $\begin{array}{r}+1,40 \\
+\end{array}$ & & 21,70 & 21 & $\begin{array}{r}0,30 \\
+0\end{array}$ & 0,0900 \\
\hline 20 & 21,00 & $-0,18$ & 0,0324 & 20,40 & 19,50 & $\begin{array}{r}0,90 \\
+\quad 0\end{array}$ & 0,8100 \\
\hline & & $-2,20$ & 4,8400 & 19,10 & 21,90 & $-2,80$ & 7,8400 \\
\hline & & $\begin{array}{r}0,35 \\
\end{array}$ & 0,1225 & 20,30 & 21,30 & $-1,00$ & 1,0000 \\
\hline 21,20 & 19 , & $\begin{array}{r}1,80 \\
+1,80\end{array}$ & 3,2400 & 20,30 & 21,50 & $-1,20$ & 1,4400 \\
\hline
\end{tabular}

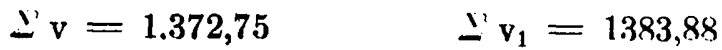


Para efelto de contróle, note-se que êste resultado deve ser igual ao que se obtém quando se faz a diferença

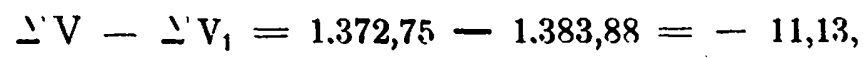

em que

$I^{\prime} V=a$ soma dos Brix das canas florescidas;

$\mathcal{L}^{\prime} \mathrm{V}_{1}=$ a soma dos Brix das canas não florescidas.

A seguir foram calculados a média e o êrro standard da média das diferenças:

$$
\begin{aligned}
& \text { dif }=\frac{-11,13}{68}=-0,1650 \\
& \sigma \overline{\text { dif }}= \pm \sqrt{\frac{y^{\prime}(\text { dif })^{2}-\frac{(\Sigma \text { dif })^{2}}{n}}{n(n-1)}}= \pm \sqrt{\frac{111,6935-\frac{(11, \overline{13})^{2}}{68}}{68.67}}= \\
& = \pm \sqrt{\frac{109,872}{68.67}}= \pm 0,15529
\end{aligned}
$$

Verificámos, então, pelo o-test que a difercnça média (dii i achada năo difere significativamente de zero:

$$
\begin{aligned}
& \jmath=\frac{-0,1650-0}{0,15529}=-1,063 \\
& g=67-\text { Insignificante }-
\end{aligned}
$$

Este test confirma, portanto, plenamente, o anterior, se é que era necessária uma confirmaçăo. 
Chegámos pelo teste $\mathbf{F}$ de SNEDECOR, que tem por fim comparar érros, aos seguintes resultados:

$$
\begin{aligned}
& \mathrm{F}=\frac{\sigma^{2} \mathrm{v}}{\sigma^{2} \mathrm{v}_{1}}=\frac{(0,14165)^{2}}{(0,10745)^{2}}=1,738 \\
& \mathrm{~g}=67 \\
& \mathrm{gl}^{2}=67-\text { Duvidoso. }
\end{aligned}
$$

O limite de $5 \%$ de probabilidades é 1,498 e o limite de $1 \%$ de probabilidades é 1,778. Estes limites foram obtidos por interpolação dupla na tabela dada por KENNEY.

Foram êstes os métodos de análise utilizados para os demais dados das 68 análises da variedade F 29-7. Nos demais casos só daremos os resultados, uma vez que a marcha foi a mesmá.

\section{Análise dos redutores}

A - Média e respectivo êrro standard:

Nas canas florescidas:

$$
\mathrm{v}=0,76298 \quad \sigma \mathrm{v}= \pm 0,032012
$$

Nas canas não florescidas:

$$
\mathrm{v}_{1}=0,74202 \quad \sigma \mathrm{v}_{1}= \pm 0,026137
$$

O valor de $\partial$ achado foi $+0,5071$ com um gráu de liberdade (g) 134. A diferença é, portanto, insignificante.

B - A média das diferenças foi

$$
\overline{\mathrm{dif}}=+0,02096
$$

O êrro standard desta média é:

$$
\begin{aligned}
\sigma \overline{\mathrm{d}} \mathrm{i} \mathrm{f} & =-1-0,03368 \\
\delta & =+0,6222 \\
\mathrm{~g} & =67-\text { Insignificante. }
\end{aligned}
$$


O teste de SNEDECOR deu os seguintes resultados:

$$
\begin{aligned}
\mathrm{F} & =\frac{\sigma^{2} \overrightarrow{\mathrm{v}}}{\sigma^{2} \mathrm{v}_{1}}=\frac{(0,032012)^{2}}{(0,026137)^{2}}=1,500 \\
\mathrm{~g} & =67 \\
\mathrm{~g} 1 & =67-\text { Duvidoso. }
\end{aligned}
$$

Análise da pol.

A - Nas canas florescidas:

$$
\overline{\mathrm{v}}=18,707 \quad \sigma \overline{\mathrm{v}}= \pm 0,15770
$$

Nas canas não florescidas:

$$
\begin{gathered}
\overline{\mathrm{v} 1=18,852} \quad \sigma \overline{\mathrm{v}} 1= \pm 0,13922 \\
\delta=-0,6893 \\
\mathrm{~g}=134-\text { Insignificante. }
\end{gathered}
$$

$$
\begin{aligned}
\mathrm{B}-\mathrm{\textrm {dii }} & =-0,14529 \\
\sigma \mathrm{di \textrm {i }} & = \pm 0,17537 \\
\delta & =-0,8285 \\
\mathrm{~g} & =67-\text { Insignificante. }
\end{aligned}
$$

Pelo teste de SNEDECOR.obtivemos:

$$
\begin{aligned}
& \mathrm{F}=\frac{\sigma^{2} \cdot \bar{v}}{\sigma^{2}-\frac{\bar{v}_{1}}{\mathrm{v}_{1}}}=\frac{(0,15770)^{2}}{(0,13922)^{2}}=1,283 \\
& \mathrm{~g}=67 \\
& \mathrm{~g}^{1}=67-\text { Insignificante. }
\end{aligned}
$$

Análise das cinzas

A - Nas canas florescidas:

$$
\overline{\mathrm{v}}=0,36672 \quad \sigma \mathrm{v}= \pm 0,0072488
$$


Nas canas não florescidas :

$$
\begin{aligned}
& \overline{\mathrm{v}} 1=0,35550 \quad \sigma \overline{\mathrm{v}} \mathrm{1}= \pm 0,0088780 \\
& \delta=0,9702 \\
& g=134 \text { - Insignificante. }
\end{aligned}
$$

$$
\begin{aligned}
\mathrm{B}-\overline{\mathrm{dif}} & =+0,011118 \\
\sigma \mathrm{dif} & = \pm 0,010318 \\
\partial & =+1,0774 \\
\mathrm{~g} & =67-\text { Insignificante. }
\end{aligned}
$$

Pelo teste de SNEDECOR:

$$
\begin{aligned}
& \mathrm{F}=\frac{\sigma_{2} \mathrm{v}_{1}}{\sigma^{2} \mathrm{v}_{\mathrm{v}}}=\frac{(0,0088780)^{2}}{(0,0072488)^{2}}=1,500 \\
\mathrm{~g}= & 67 \\
\mathrm{~g}^{1}= & 67 \text { - Duvidoso. }
\end{aligned}
$$

Análise da acidez sulfúrica

A - Nas canas florescidas:

$$
v=0,53495 \quad \sigma v= \pm 0,0017561
$$

Nas canas não florescidas:

$$
\begin{gathered}
\vee 1=0,5526 \quad \sigma \vee 1=+0,017611 \\
\delta=-0,7097 \\
g=134-\text { Insignificante. }
\end{gathered}
$$

$$
\begin{aligned}
\mathrm{B}-\mathrm{dif} & =-0,017647 \\
\sigma \mathrm{dif} & = \pm 0,01622 \\
\delta & =-1,088 \\
\mathrm{~g} & =67-\text { Insignificante. }
\end{aligned}
$$


Pelo teste de SNEDECOR :

$$
\begin{aligned}
\mathrm{F}=\frac{\sigma^{2} v_{1}}{\pi^{2}}=\frac{\left(0,017611 \mathrm{r}^{2}\right.}{(0,017561)^{2}}=1,006 \\
\mathrm{~g}=67 \\
\mathrm{~g}_{1}=67-\text { Insignificante }
\end{aligned}
$$

Análise de litros de caldo por quilo de cana

A - Nas canas florescidas:

$$
\overline{\mathrm{v}}=0,42361 \quad \sigma \overline{\mathrm{v}}= \pm 0,006592
$$

Nas canas não florescidas:

$$
\begin{gathered}
\overline{\mathrm{v}}_{1}=0,47014 \quad \sigma \overline{\mathrm{v}}_{1}= \pm 0,012729 \\
\delta=-3,246 \\
\mathrm{~g}=134 \quad \text { Significante. }
\end{gathered}
$$

Neste caso o valor de o) $(3,246)$ ultrapassa o limite de $1 \%$ que é 2,58. A diferença entre as médias, que é de 0,04653 litros de caldo por quilo de cana tem, portanto, significação estatística. Essa diferença corresponde a $9,90 \%$ da média das canas não florescidas. Donde se conclui que as canas florescidas procuzem $\mathbf{9 , 9 0 \%}$ menos caldo do que as canas não florescidas. Esse resultado, aliás, já era esperado, pois são comuns os gomos com medula sêca nas canas florescidas, o que deve evidentemente diminuir a quantidade de caldo.

A verdadeira diferença oscila em tôrno dessa média de $9.90 \%$. Podemos afirmar que em $\mathbf{8 0 \%}$ dos casos, a diferença estará entre $5,99 \%$ e $13,80 \%$. Em $90 \%$ dos casos será superior a $5,99 \%$.

$$
\begin{aligned}
\mathbf{B}-\overline{\mathrm{dif}} & =-0,04653 \\
\sigma \mathrm{dif} & = \pm 0.011946 \\
\phi & =-3,895 \\
\mathrm{~g} & =67-\text { Significante. }
\end{aligned}
$$

Neste caso podemos dizer que em $80 \%$ dos casos a diferença estará entre $6,64 \%$ e $13,15 \%$ e em $90 \%$ dos casos será supezior a $6,64 \%$. A diferença déstes limites para os anteriormen- 
te determinados se explica pelo fato de, neste caso, serem comparados dados colhidos no mesmo dia, o que aumenta a significaçăo das diferenças observadas. lados :

Pelo teste de SNEDECOR, obtivemos os seguintes resul-

$$
\begin{aligned}
\mathrm{F}=\frac{\sigma^{2} \overline{v_{1}}}{\sigma^{2}} \frac{\bar{v}_{\mathrm{v}}}{\mathrm{v}}=\frac{(0,012729)_{2}}{(0,006592)^{2}}=4.728 \\
\mathrm{~g}=67 \\
\mathrm{~g}_{1}=67 . \text { Significante }
\end{aligned}
$$

Por ai vemos que o único teste $F$ significante foi o úlimo, referente aos litros de caldo por quilo de cana. He nos indica que o êro é significativamente maior nas canas năo florescidas, isto é, que o florescimento tende a estabilizar a relaçăo litros ae caldo por quilo. de cana, da mesma maneira como acontece com o pesso, como veremos adiante.

\section{Análise da fibra}

A - Nas canas florescidas:

$$
\overline{\mathrm{v}}=12,565 \quad \sigma \mathrm{v}= \pm 0,10532
$$

Nas canas não florescidas:

$$
\begin{aligned}
& \ddot{v}_{1}=12,179 \\
& \sigma \cdot v_{1}= \pm 0,11850 \\
& \text { d }=+2,5125 \\
& \mathbf{g}=134 \text { - Duvidoso. } \\
& \mathbf{B}-\overline{\mathrm{dif}}=+0,38515 \\
& n \text { dif }= \pm 0,13738 \\
& \delta=+2,8035 \\
& \mathrm{~g}=67 \text { - Significante. }
\end{aligned}
$$

Pelo teste de SNEDECOR chegámos ao seguinte:

$$
\begin{aligned}
\mathrm{F}=\frac{\sigma_{2} v_{1}}{n^{2} v} & =\frac{(0,11850)^{2}}{(0,10532)^{2}}=1,266 \\
\mathrm{~g} & =67 \\
\mathrm{~g}_{1} & =67-\text { Insignificante }
\end{aligned}
$$


Pelos resultados acima obtidos na análise estatística da ijbra da F 29-7, chegámos a um resultado duvidoso. Năo obstante, grande numero de autores admite que as canas florescidas sto, por via de regra, 2 a 2,5 vezes mais moles que as canas năo florescidas. Se considerarmos apenas as médias v e v 1 , chegaremos a uma conclušo diferente, isto $e$, que as canas florescidas acusam maior \% de flbra que as nôo florescidas.

Nas análises efetuadas sóbre canas florescidas constatámos que estas apresentavam, quase sempre, uma medula oca, a qual, em muitas variedades, se estendia da ponta do colmo ao pe. Ademais, sem exceçá, as canas florescidas sempre apresentavam os internodios da ponta com a medula seca. se caracteristico, em certas variedades, como na Co. 312 e Tuc. 519 era táo intenso que muitas vezes tivemos grande dificuldade para extrair desses internodios, por prensagem, algumas gotas de caldo para efetuarmos a determinaçáo da matéria seca pelo refratometro Zeiss. isse fato, só muito rarainente fol encontrado em canas nao florescidas. Nestas, a medula sêca comegava a se manifestar justamente quando o colmo estava prestes a emitir o escapo floral. Acreditamos mesino que se possa admitir que a intensidade de gomos com medula seca esteja em relação direta com a aproximaçăo do aparecimento da inflorescencia. Talvez al esteja a explicaçáo dos resultados por nos obtidos.

\section{Análise do pêso das canas}

Em relaçăo as variaçరes do peso nas canas florescidas e náo florescidas o numero dos dados disponivels fol maior. $\mathrm{Ca}-$ da dia foram pesadas 3 canas separadamente, dando em 68 dias 204 pesagens. 204 dados foram somados e assim obtivemos, para as canas florescidas:

$$
\Sigma \mathrm{v}=222,583
$$

- Com esse valor (Quadro II) fol calculada a correçáo C pela formula seguinte:

$$
\mathrm{C}=\frac{(\Sigma v)^{2}}{\mathrm{n}}=\frac{(222,583)^{2}}{204}=242,8588
$$

Cada um dos 204 dados fol elevado ao quadrado, e esses quadrados foram somados, dando como resultado:

$$
\text { ¿ } v^{2}=262,956.5
$$


Esse total menos a correçåo (C) nos deu a soma dos quadrados dos desvios:

$$
\begin{aligned}
\Sigma \mathrm{d}^{2} & =262,9565-242,8588=20,0977 \\
\mathrm{~g} & =204-1=203 .
\end{aligned}
$$

Foran depuis somados separariamente os pesos das 3 canas pesadas em cada dia, e cada uma dessas somas de 3 parcelas foi elevada ao quadrado. A soma desses qudrados deu 750,6784. Com este total foi calculada a soma dos quadrados dos desvios devidos à variaçáo diária:

$$
\begin{aligned}
\frac{750,6784}{3}-\mathrm{C} & =7,3673 \\
\mathrm{~g}_{1} & =68-1=67
\end{aligned}
$$

Achámos o resto com o respectivo grau de liberdade.

$$
\begin{aligned}
\text { Resto } & =20,0977-7,3673=12,7304 \\
\mathbf{g}_{2} & =203-67=136
\end{aligned}
$$

Com êsses dadus calculámos o êrro devido à variação diária $\left(\sigma_{1}\right)$ e o êrro experimental $\left(\sigma_{2}\right)$.

$$
\begin{aligned}
& \sigma_{1}= \pm \sqrt{\frac{7,3673}{67}}= \pm 0,33160 \\
& \sigma_{2}= \pm \sqrt{\frac{12,7304}{136}}= \pm 0,30595
\end{aligned}
$$

O quadro seguinte resume esses cálculos:

\section{QUADRO II}

\begin{tabular}{l|r|r|r}
\hline Discriminação & $\Sigma(\text { desvios })^{2}$ & $\begin{array}{r}\text { Grau de } \\
\text { liberdade }\end{array}$ & Erro \pm \\
\hline $\begin{array}{l}\text { Variação diária } \\
\text { Resto }\end{array}$ & 7,3673 & $\mathbf{g}_{1}=67$ & $\mathbf{0 , 3 3 1 6 0}$ \\
\hline Total & 12.7304 & $\mathbf{g}_{2}=136$ & $\mathbf{0 , 3 0 5 9 5}$ \\
\hline
\end{tabular}


Fizemos o teste de SNEDECOR com os seguintes resultados:

$$
\begin{aligned}
& F=\frac{(0,33160)^{2}}{(0,30595)^{2}}=1,1747 \\
& g_{1} \doteq 67 \\
& g_{2}=136-\text { Insignificante. }
\end{aligned}
$$

Nas canas não florescidas obtivemos:

$$
\begin{aligned}
\check{v} & =208,7460 \\
\mathrm{C} & =212,9848
\end{aligned}
$$

QUADRO III

\begin{tabular}{l|c|c|c}
\hline Discriminação & $\Sigma(\text { desvios })^{2}$ & $\begin{array}{c}\text { Grau de } \\
\text { liberdade }\end{array}$ & Erro \pm \\
\hline \begin{tabular}{c|c} 
ariaçåo diária \\
Resto
\end{tabular} & 12,3391 & $\mathrm{~g}_{1}=67$ & 0,42915 \\
\hline Total & 5,9669 & $\mathrm{~g}_{2}=136$ & 0,20946 \\
\hline
\end{tabular}

Segundo o teste de SNEDECOR :

$$
\begin{aligned}
& F=\frac{(0,42915)^{2}}{(0,20946)^{2}}=4,198 \\
& g_{1}=67 \\
& g_{2}=136-\text { Significante. }
\end{aligned}
$$

O êrro da diferença entre as canas florescidas e as canas „âo florescidas é:

$$
\begin{gathered}
\sigma \overline{\mathrm{dif}}= \pm \sqrt{(0,30595)^{2}+(0,20946)^{2}}=+0,3708 \\
\delta=\frac{1,0911-1.0233}{0,3708}=+0,1828 \\
g=272-\text { Insignificante. }
\end{gathered}
$$

Conclui-se que o pequeno excesso de pêso das canas floresctalas sôbre as canas năo ifłorescidas não tem significação es- 
tatística. $O$ teste $F$ insignificante nas canas florescidas indica que o péso se torna estável com o florescimento, ao contrário do que acontece com as canas não florescidas.

\section{Análise estatística dos dados da VARIEDadE Co. 285}

Para a análise estatística das 32 observações efetuadas na Co. 285 utilizámos apenas o método B já conhecido. Em todos os casos, as médias representadas por $\bar{v}$ se referem às canas florescidas e as médias indicadas por $v_{1}$ se referem às canas não florescidas.

\section{Análise do Brix}

$$
\begin{aligned}
\overline{\mathrm{v}}=18,9550 & \quad \mathrm{v}_{1}=18,8769 \\
\sigma \overline{\mathrm{dif}} & =0,0781 \\
\sigma \overline{\mathrm{dif}} & = \pm 0,1463 \\
\delta & =+0,534 \\
\mathrm{~g} & =31-\text { Insignificante. }
\end{aligned}
$$

Análise dos redutores

$$
\begin{aligned}
\cdots=0,94024 & \overline{\mathrm{v}}_{1}=1,0374 \\
\overline{\mathrm{dif}} & =-0,09716 \\
\sigma \overline{\mathrm{dif}} & = \pm 0,05219 \\
\delta & =\overline{-1}, 861 \\
\mathrm{~g} & =31-\text { Insignificante. }
\end{aligned}
$$

Análise da pol

$$
\begin{aligned}
\overline{\mathrm{v}}=16,4344 & \overline{\mathrm{v}}_{1}=16,1247 \\
\overline{\mathrm{dif}} & =+0,3097 \\
\sigma, \overline{\mathrm{dif}} & = \pm-14286 \\
\delta & = \pm 2,168 \\
\mathrm{~g} & =31-\text { Duvidoso. }
\end{aligned}
$$




\section{Análise : das cinzas}

Neste caso houve apenas 31 análises, pois a 32.a se perdeu.

$$
\begin{aligned}
\bar{v}=0,46421 & \bar{v}_{1}=0,56535 \\
\overline{\text { dif }} & =-0,10115 \\
\sigma \overline{\mathrm{dif}} & = \pm 0,02834 \\
\delta & =-3,569 \\
\mathrm{~g} & =30-\text { Significante. }
\end{aligned}
$$

Análise da acidez sulfúrica

$$
\begin{aligned}
\overline{\mathrm{v}}=0,79719 & \quad \overline{\mathrm{v}}_{1}=0,94756 \\
\overline{\mathrm{dif}} & =-0,15037 \\
\sigma \overline{\mathrm{dif}} & = \pm 0,053446 \\
\delta & =-2,916 \\
\mathrm{~g} & =31-\text { Significante. }
\end{aligned}
$$

Análise dos litros de caldo por quilo de cana

'Tembém aqui, como no caso das cinzas, houve apenas 31 dados a analisar.

$$
\begin{aligned}
\overline{\mathrm{v}}=0,29813 & \overline{\mathrm{v}}_{1}=0,35055 \\
\overline{\mathrm{dif}} & =-0,05242 \\
\sigma \overline{\mathrm{dif}} & = \pm 0,009969 \\
\delta & =-5,258 \\
\mathrm{~g} & =30-\text { Significante. }
\end{aligned}
$$

$\Lambda$ diferença observada de 0,05242 litros de caldo por quilo de cana a menos nas canas florescidas do que nas canas náo florescidas representa $14,95 \%$ a menos, suposta igual a 100 a média das canas não florescidas. Podemos afirmar que em $80 \%$ dos casos essa diferença estará entre $9,23 \%$ e $20,67 \%$. Em $30 \%$ dos casos será superior a $9,23 \%$. 
Análise da fibra

$$
\begin{aligned}
\overline{\mathrm{v}}=17,8288 & \cdots_{1}=16,6968 \\
\overline{\mathrm{dif}} & =+1,1320 \\
\sigma \overline{\mathrm{dif}} & = \pm 0,20613 \\
\delta & = \pm 5,4915 \\
\mathrm{~g} & =31-\text { Significante. }
\end{aligned}
$$

Análise estatística dos dados da VARIEDADE Co. 312

Neste caso também só usámos o método $\mathbf{B}$ na análise dos is dacios disponiveis.

Análise do Brix

$$
\begin{array}{rlr}
\bar{v}=19,7116 & \quad \overline{v_{\mathrm{t}}}=20,2453 \\
\overline{\mathrm{dif}} & =-0,5337 \\
\sigma \overline{\mathrm{dif}} & = - \pm 0,2325 \\
\delta & =-2,295\left(^{*}\right) \\
\mathrm{g} & =18
\end{array}
$$

O limite de $5 \%$ é 2,101 e o de $1 \%$ é 2,878 . O resultado é, portanto, duvidoso.

Análise dos redutores

$$
\begin{aligned}
\overline{\mathrm{v}}=0,5315 & \overline{\mathrm{v}}_{\mathrm{s}}=0,7220 \\
\overline{\mathrm{dif}} & =-0,1905 \\
\sigma \overline{\mathrm{dif}} & = \pm 0,07438 \\
\delta & =-2,561 \\
\mathrm{~g} & =18-\text { Duvidoso. }
\end{aligned}
$$

Análise da pol

$$
\begin{aligned}
\mathrm{v}=18,18526 & \quad \bar{v}_{1}=18,31684 \\
\sigma \mathrm{dif} & =-0,13158 \\
\sigma \mathrm{dif} & = \pm 0,2823 \\
\delta & =-0,466 \\
\mathrm{~g} & =18-\text { Insignificante. }
\end{aligned}
$$

(*) Para maior uniformidade os autores resolveram usar a letra mesmo nos casos em que o grau de liberdade é menor que 30. 
Análise das cinzas

$$
\begin{aligned}
\bar{v}=0,33289 & v_{1}=0,30822 \\
\text { difi } & =+0,02467 \\
n \text { dif } & = \pm 0,02266 \\
\delta & =+1,089 \\
g & =18-\text { Insignificante. }
\end{aligned}
$$

And́lise da acidez sulfúrica

$$
\begin{aligned}
v=0,49816 & \quad v_{1}=0,68232 \\
\overline{\mathrm{dif}} & =-0,18416 \\
\sigma \overline{\mathrm{dif}} & = \pm 0,05286 \\
0 & =-3,481 \\
\mathrm{~g} & =18-\text { Significante. }
\end{aligned}
$$

Análise dos litros de caldo por quilo de cana

$$
\begin{aligned}
& \bar{v}=0,33511 \bar{v}_{1}=0,40.358 \\
& \overline{\text { dif }}=-0,06847 \\
& \sigma \overline{\text { dif }}= \pm 0,017151 \\
& \delta=-3,992 \\
& g=18-\text { Significante. }
\end{aligned}
$$

Suposta igual a 100 a média das canas não florescidas, a diferença média achada corresponde a 16,97\%. Em $80 \%$ dos casos essa diferença estará entre 11,52\% e $22,41 \%$. Em $90 \%$ dos casos será superior a $11,52 \%$.

Análise da fibra

$$
v=15,4121 \quad \therefore \quad v_{1}=13,9700
$$

$$
\begin{aligned}
\overline{\mathrm{dif}} & =+1,4421 \\
\sigma \mathrm{dif} & = \pm 0,33519 \\
\delta & =4,3024 \\
\mathrm{~g} & =18 \ldots \text { Significunte }
\end{aligned}
$$


Análise estatística dos dados da VARIEDADE Tuc. 519

O método de análise usado foì 0 método B. $O$ número de cinálises foi de 26.

Análise do Brix

$$
\begin{aligned}
\overline{\mathrm{v}}=15,9119 & \mathrm{v}_{1}=15,8358 \\
\overline{\mathrm{di}} \overline{\mathrm{i}} & = \pm+0,0761 \\
\sigma \overline{\mathrm{dif}} & = \pm 0,2018 \\
\partial & = \pm 0,3774 \\
\mathrm{~g} & =25-\text { Insignificante. }
\end{aligned}
$$

O limite de $5 \%$ é 2,060 e o de $1 \%$ é de 2,787 .

Análise dos redutores

$$
\begin{aligned}
\ddot{\mathrm{v}}=2,7027 & \overline{\mathrm{v}}_{1}=3,4971 \\
\overline{\mathrm{dif}} & =-0,7944 \\
\sigma \overline{\mathrm{dif}} & = \pm 0,16373 \\
\delta & =-4,852 \\
\mathrm{~g} & =25-\text { Significante }
\end{aligned}
$$

Análise da pol

$$
\begin{aligned}
\vec{v}=11,3050 & \bar{v}_{1}=10,3950 \\
\overline{\text { dif }} & =+0,9100 \\
g \overline{\text { dif }} & = \pm 0,3767 \\
\delta & = \pm 2,416 \\
g & =25-\text { Duvidoso. }
\end{aligned}
$$

Análise das cinzas

$$
\begin{aligned}
\mathrm{v}=0,43687 & \quad \mathrm{v}_{1}=0,52836 \\
\sigma \overline{\mathrm{dif}} & =-0,09149 \\
\mathrm{dif} & = \pm 0,03784 \\
\delta & = \pm .2,418 \\
\mathrm{~g} & =24-\text { Duvidoso. }
\end{aligned}
$$

Neste caso, por exceção, só houve 25 dados a analisar. 
Análise da acidez sulfúrica

$$
\begin{aligned}
\overrightarrow{\mathrm{v}}=0,66892 & \quad \mathrm{v}_{1}=0,77831 \\
-\overline{\mathrm{dif}} & =-0,10939 \\
\sigma \overline{\mathrm{dif}} & = \pm 0,060486 \\
\delta & =-1,8085 \\
\mathrm{~g} & =25-\text { Insignificante. }
\end{aligned}
$$

Análise dos litros de caldo por quilo de cana

$$
\begin{aligned}
\bar{v}=0,32554 & \quad \bar{v}_{1}=0,36904 \\
\overline{\text { dif }} & =-0,04350 \\
\sigma \text { dif } & = \pm 0,017302 \\
\delta & =-2,514 \\
\mathrm{~g} & =25-\text { Duvidoso. }
\end{aligned}
$$

Análise da fibra

$$
\begin{aligned}
\overline{\mathrm{v}}=20,0188 & \quad \overline{\mathrm{v}}_{1}=19,2077 \\
\overline{\text { dif }} & = \pm 0,8112 \\
\sigma \overline{\text { dif }} & = \pm 0,3162 \\
\delta & = \pm 2,565 \\
\mathrm{~g} & =25-\text { Duvidoso. }
\end{aligned}
$$

RESUMO E INTERPRETAÇAO DA ANALISE ESTATISTICA

\section{1 - Análise do Brix}

Em três das variedades analisadas - F 29-7, Co. 285 e Tuc. 519, - a diferença entre o Brix do caldo das canas florescidas e das canas năo florescidas foi estatisticamente insignificante. Apenas em uma variedade - Co. 312 - tivemos um resultado duvidoso.

Em F 29-7 nota-se que o êrro nas canas florescidas é maior que nas não florescidas, o que.parece indicar uma tendéncia a maior instabilidade do Brix com o florescimento. A diferença entre os dois êrros é, porém, de significação duvidosa, embora 
o valo: de $\mathbf{F}$ exceda bastante o limite de $5 \%$ de probabilidade, sem atingir o de $1 \%$.

\section{2 - Análise dos redutores}

Houve uma diferença sem significação em F 29-7 e Co. 285. İm Co. 312, porém, o resultado foi duvidoso e em Tuc. 519 foi significante, e em ambas estas variedades as canas náo florescidus eram as mais ricas em redutores, o que merece ser salientado.

Nota-se que o êrro nas canas não florescidas é maior do que nas florescidas, o que indica uma estabilização de percen-tagem de redutores com o florescimento em F 29-7. A diferença entre os êrros é, porém, de significaçåo duvidosa, de sorte que só futuras pesquisas poderão esclarecer essa dúvida.

\section{3 - Análise da pol}

Neste caso a diferença foi Insignificante em F 29-7 e Co. 312 e duvidosa nas outras duas variedades. $\mathbf{E}$ nos casos de diferensa duvidosa a pol fol maior no caldo das canas florescidas, o que é digno de destaque.

O erro fol insignificantemente maior nas canas florescidas do que nas năo florescidas.

\section{4 - Análise das cinzas}

A diferença entre as médias fol insignificante em F 29-7 e Co. 312; foi duvidosa em Tuc. 519 e significante em Co. 285. Nos dois últimos casos a quantidade de cinzas foi maior no caldo das canas năo florescidas do que no das florescidas.

Nota-se, pelo êrro, uma maior variaçăo nas canas năo florescidas, mas o teste $F$ dá um resultado duvidoso, que exige novas-pesquisas.

\section{5 - Análise da acidez sulfúrica}

A diferença entre as médias foi insignificante em F 29-7 e Tuc. 519, tendo sido significante nas duas variedades restantes. Nestes dôis últimos casos foi o caldo das canas florescidas iavorecido com uma acidez menor do que o das não florescidas. 
O teste $\mathbf{F}$ fol absolutamente sem significaça, o que significa que a variaçáo é a mesma nas canas florescidas e náo florescidas em $F$ 29-7.

\section{6 - Análise de litros de cadlo por quilo de cana}

A diferença entre as médias fol significante em F 29-7, Co. 285 e Co. 312, sempre com menor quantidade de caldo nas canas náo florescidas. Em Tuc. 519 o resultado fol duvidoso, mas como se aproxima bastante do limite de $1 \%$ e concorda com os resultados obtidos nas outras variedades e ainda com a observaçáo dè medula seca nos gomos terminals das canas florescidas, como já fol dito atrás, esse resultado pode ser tomado como significante.

O èrro malor nas canas náo florescidas e o teste $F$ significante indicam que com o florescimento se estabiliza a relaçāo litros de caldo por quilo de cana.

\section{7 - Anślise da fibra}

Neste caso os resultados foram análogos aos obtidos no caso da relaçáo litros de caldo por quilo de cana, como era de se esperar. De fato, em F 29-7, Co. 285 e Co. 312 as diferenças foram significantes. Em Tuc. 519 o resultado fol duvidoso, mas as mesmas consideraçסes apresentadas no caso anterior nos levam a considerá-10 significante.

$\mathrm{Em}$ todas as variedades analisadas as canas florescidas foram sempre mais ricas em fibra. $O$ teste $F$ foi insignificante, c que indica que năo há diferença notável entre os erros.

\section{8 - Análise do péso}

Esta análise, que só foi feita em F 29-7, nos leva a concluir que o pequeno excesso de peso apresentado pelas canas florescidas năo tem a menor significaçáo. Como as nossas observaçōes indicam para as canas florescidas maior comprimento e maior grossura, esse resultado evidencia um murchamento, o que é, aliás, confirmado pela diminuiçăo da relaçăo litros de caldo por quillo de cana e pelo aumento da quantidade de fibra:

Sóbre o teste $F$ já salientámos que êle neste caso nos indica que o peso das canas se estabiliza com o florescimento. 


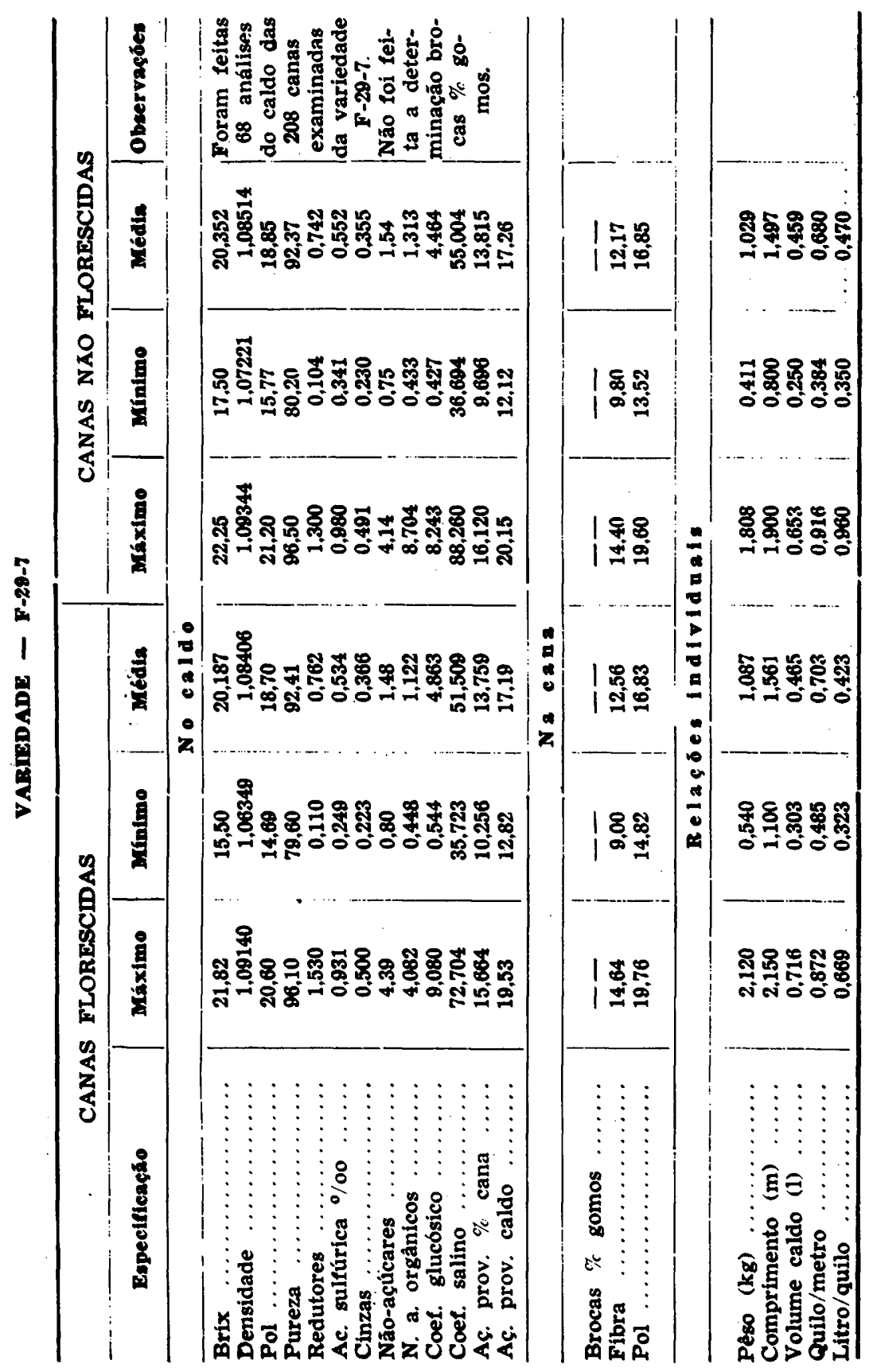




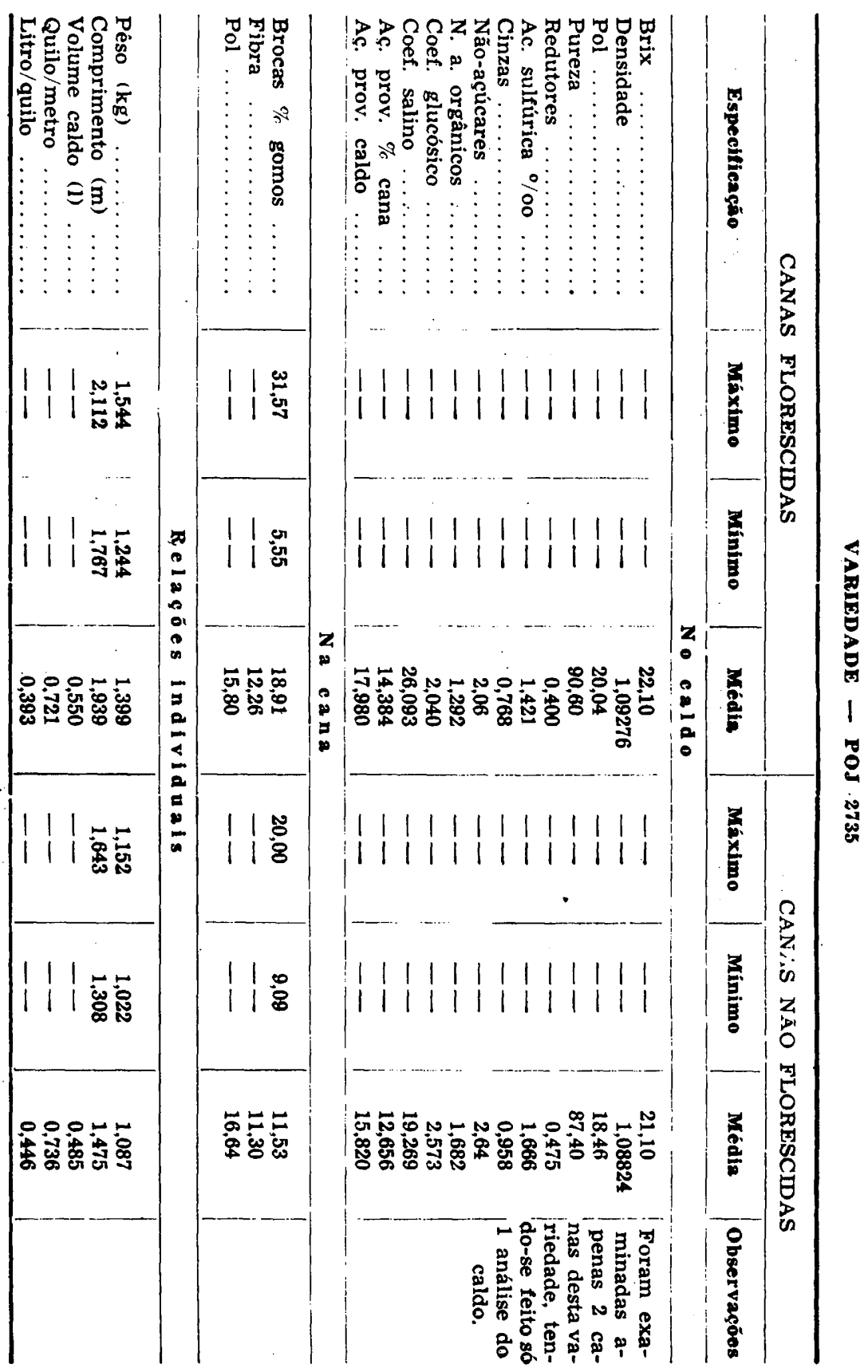




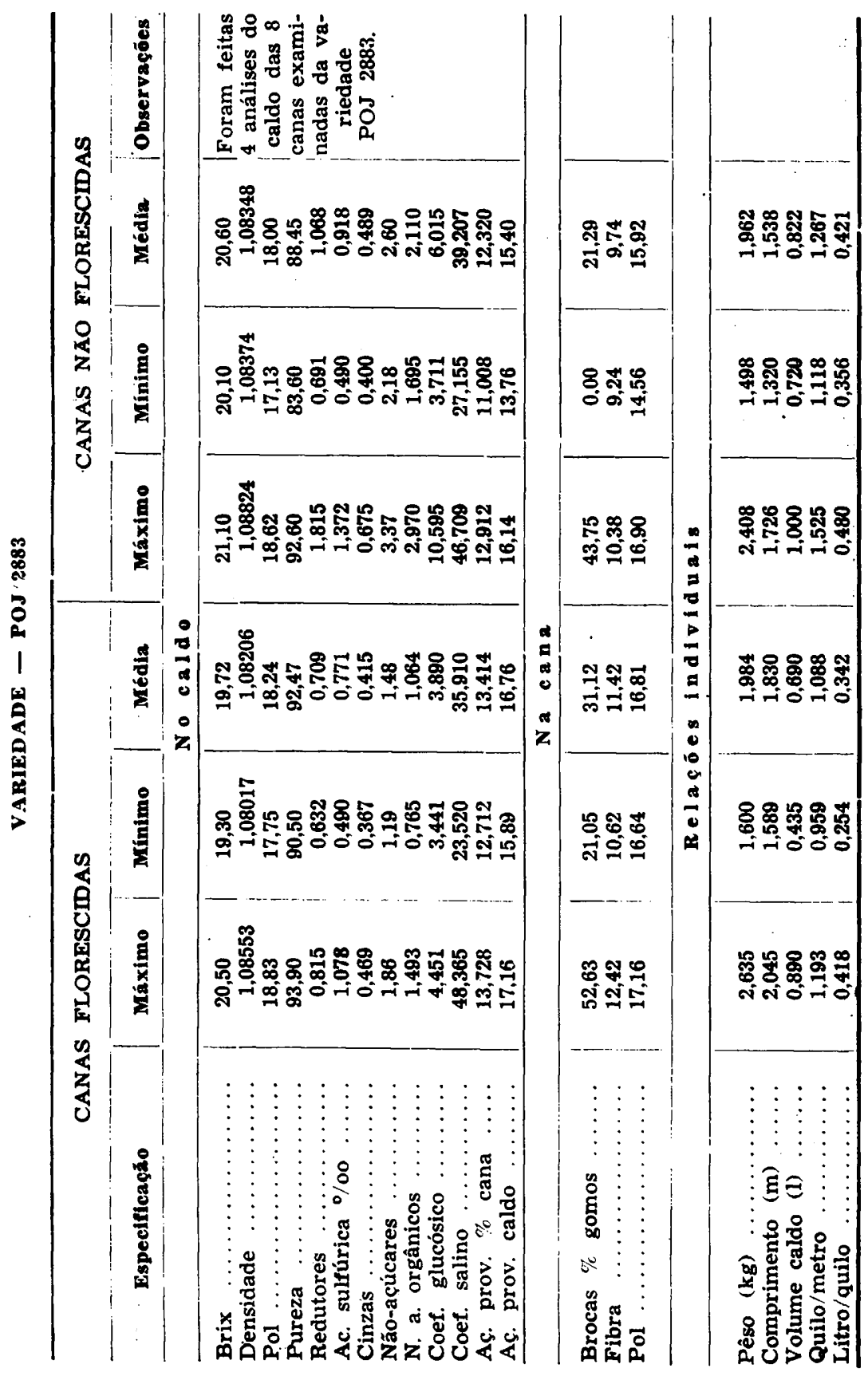




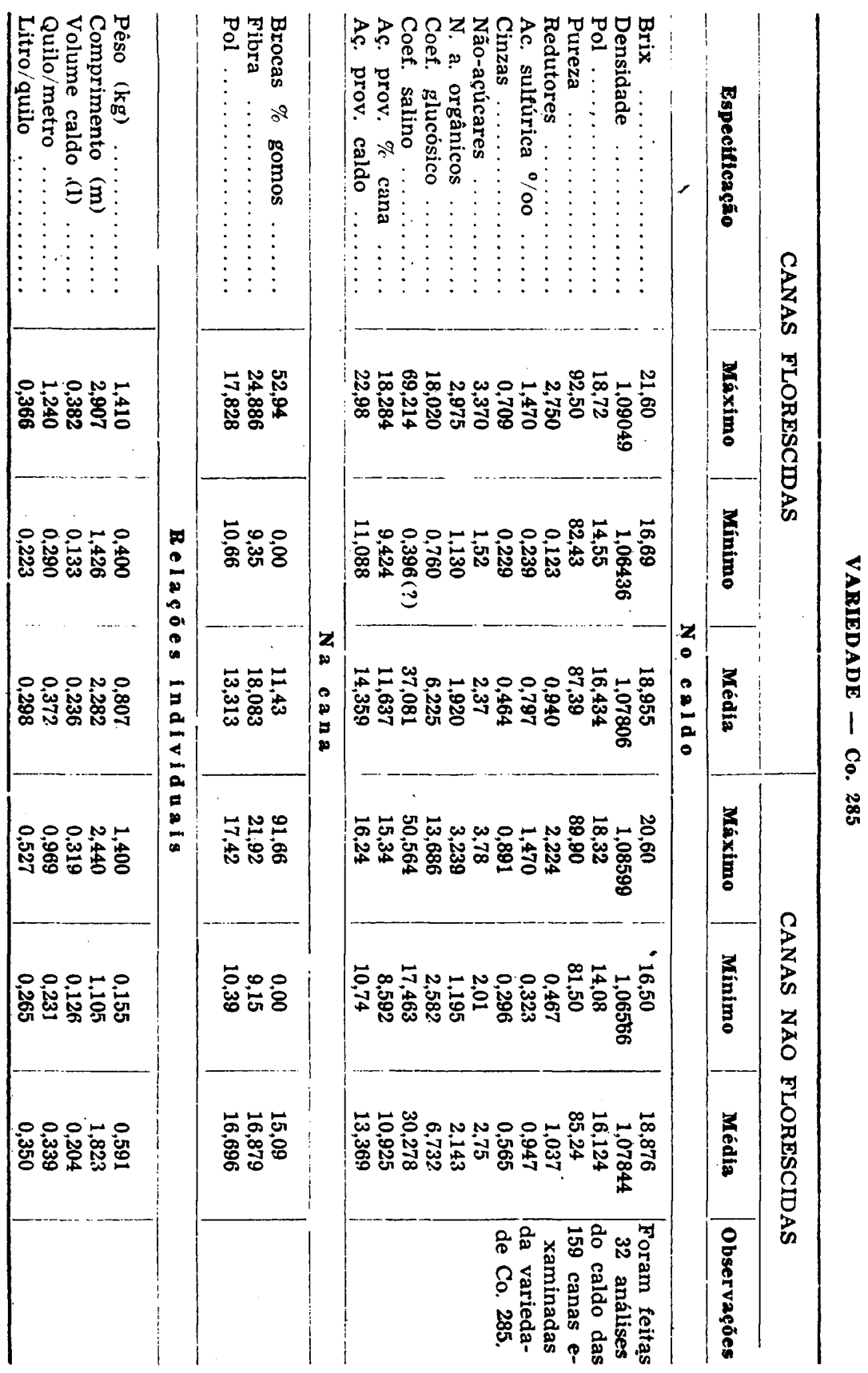




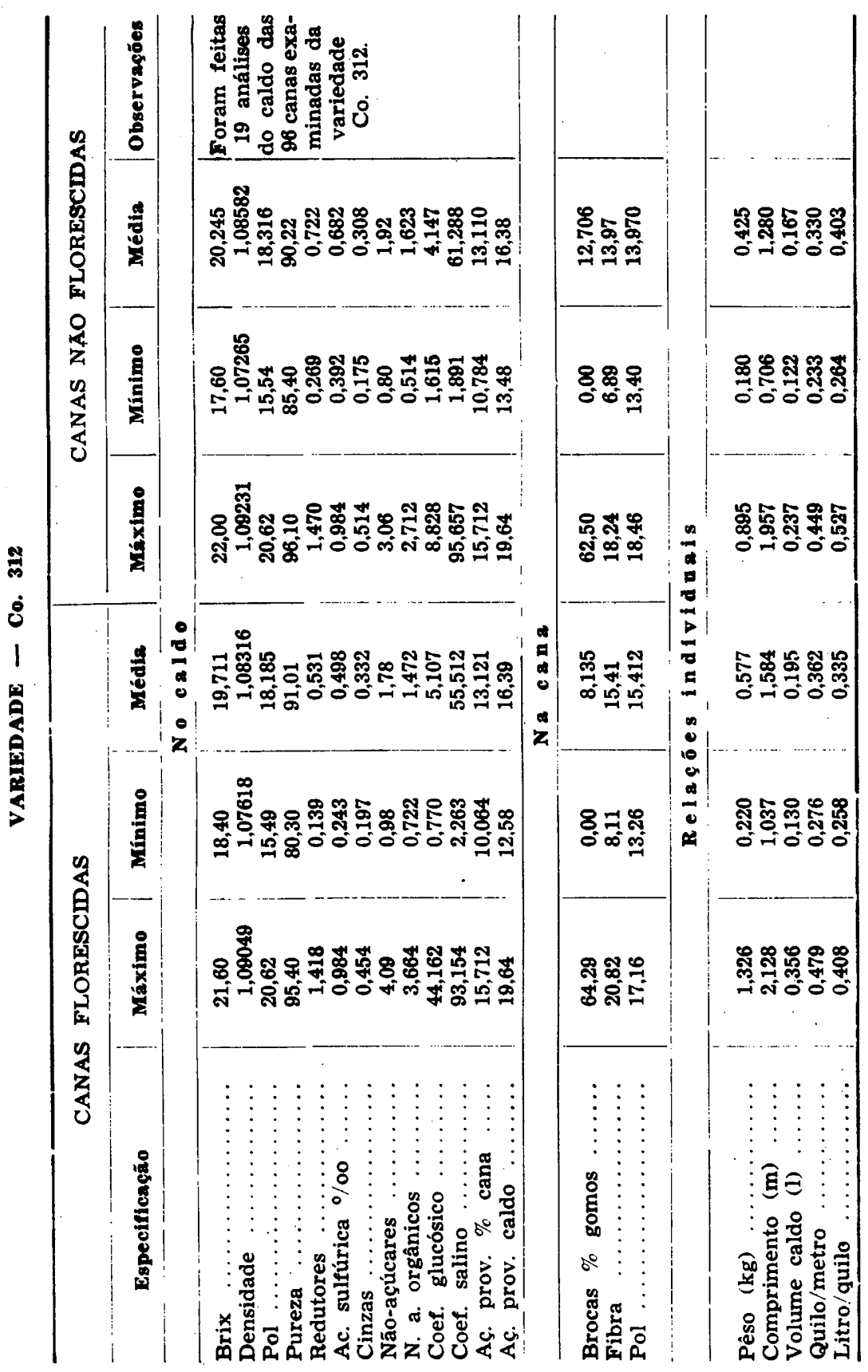




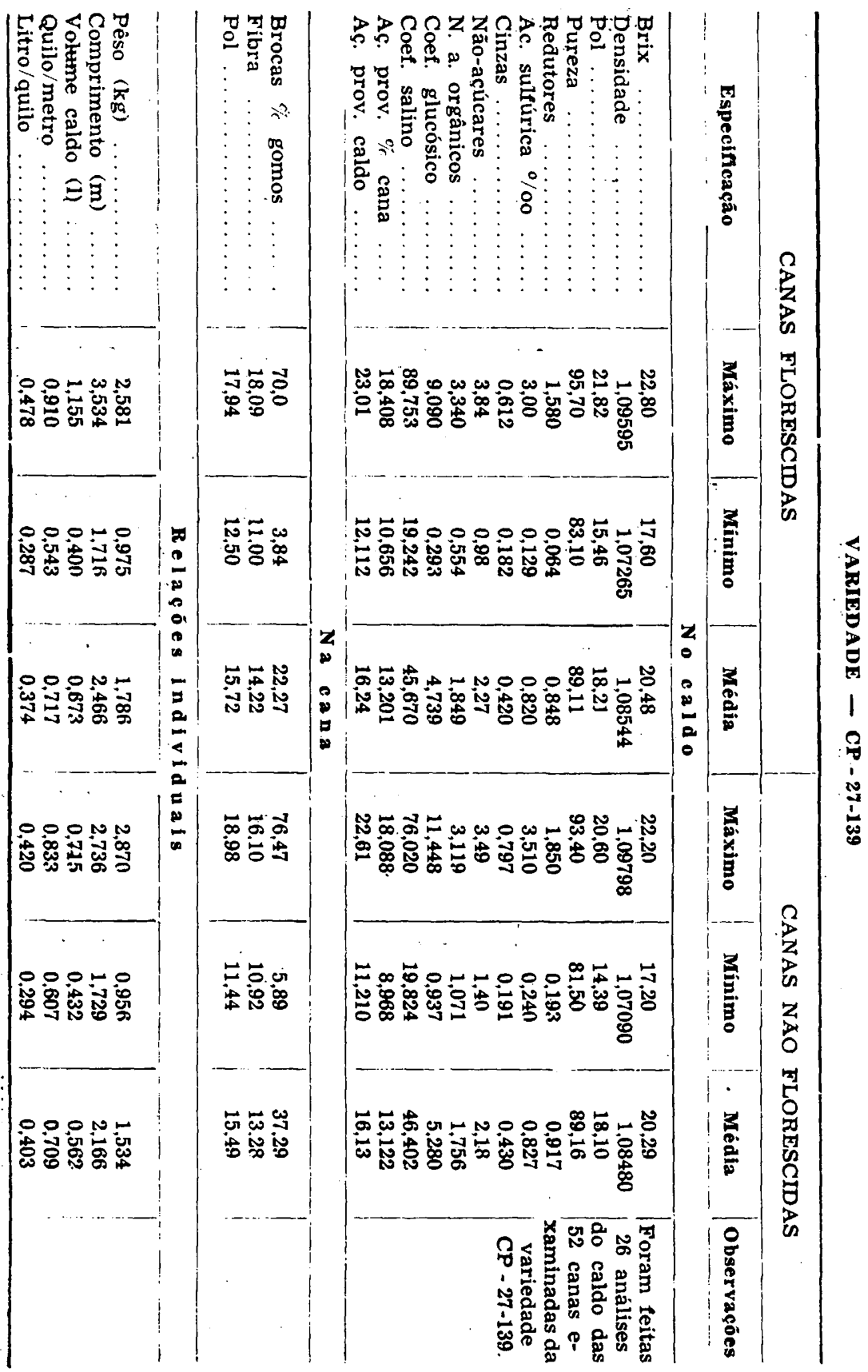




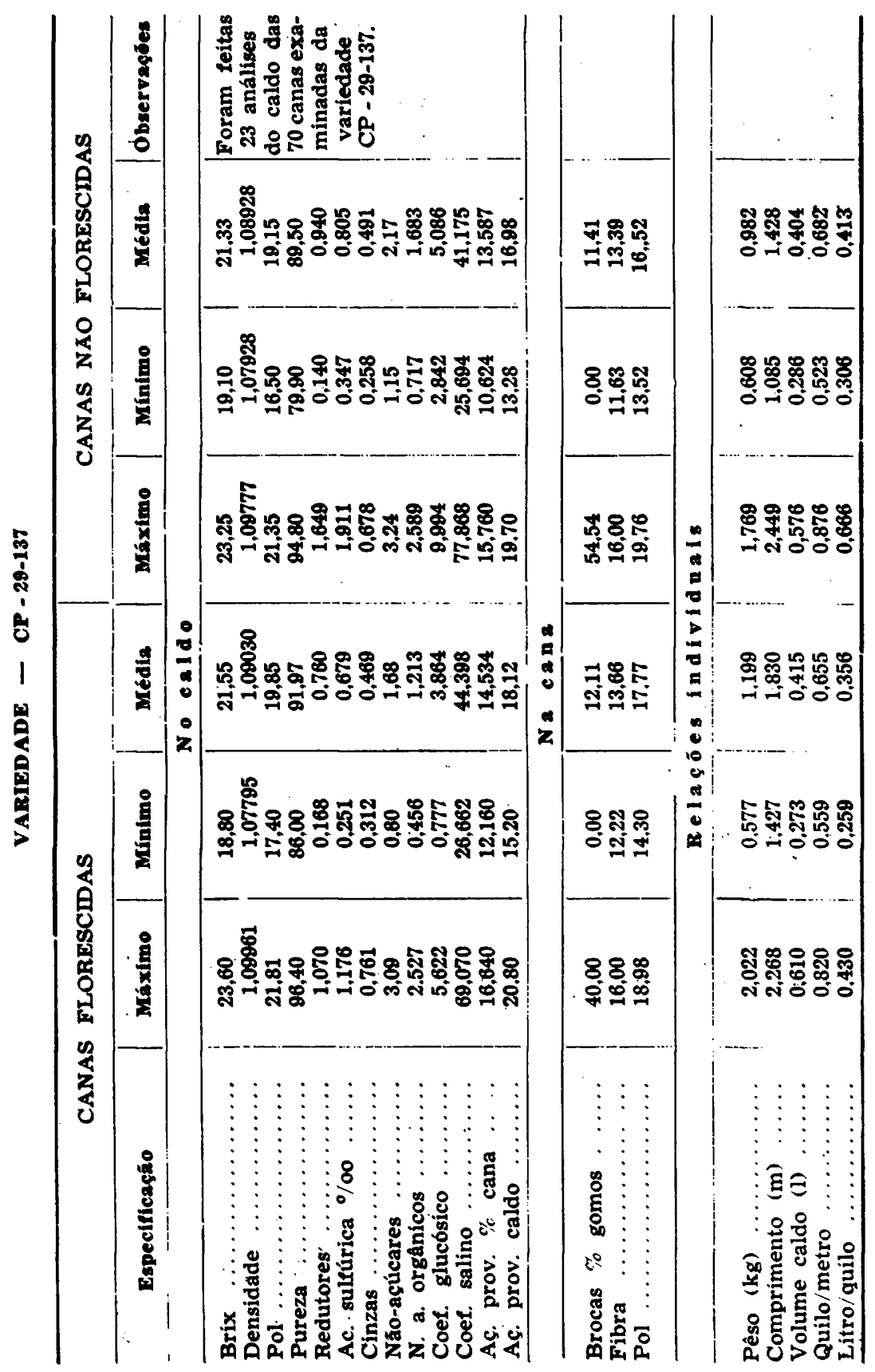




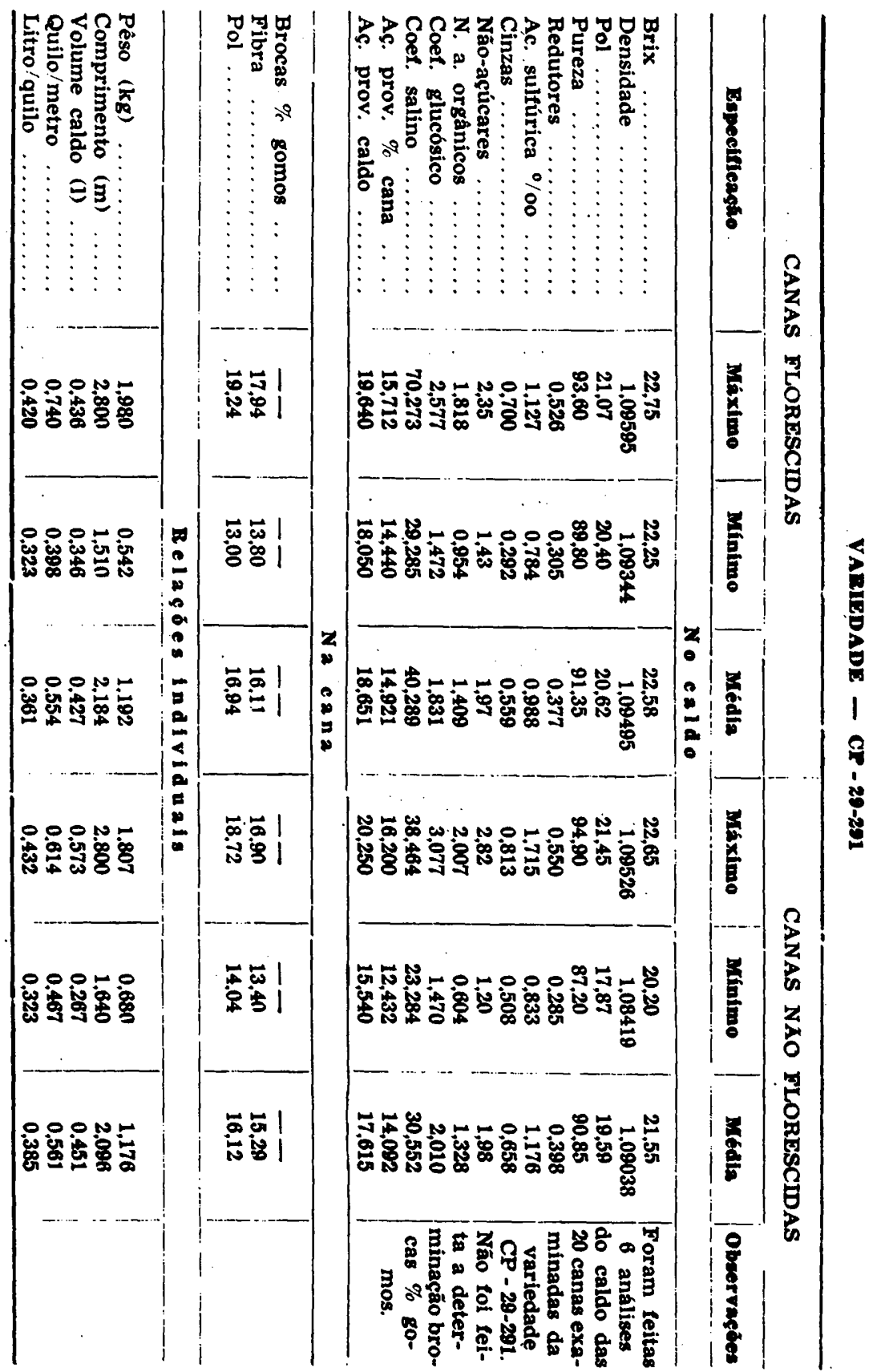




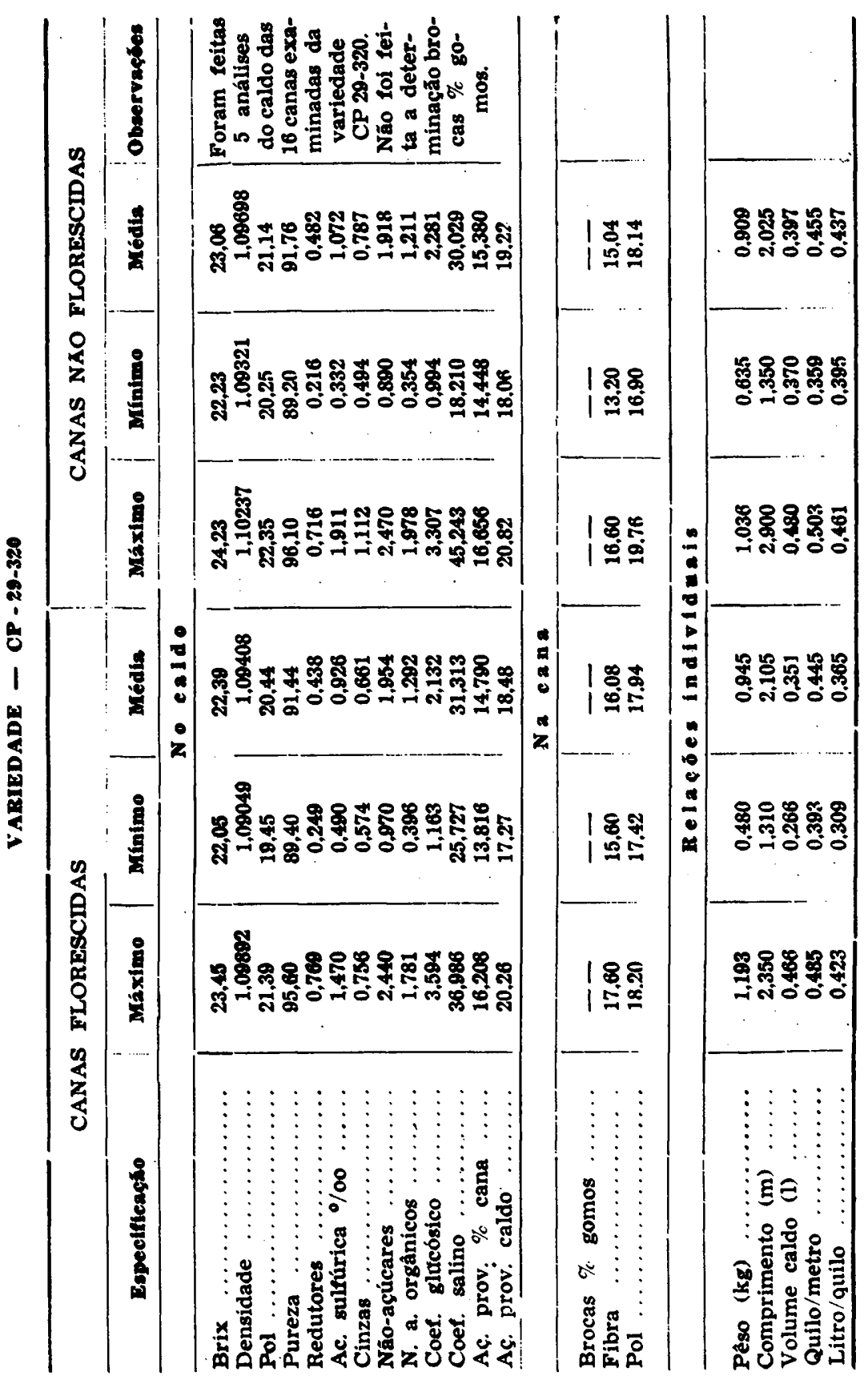




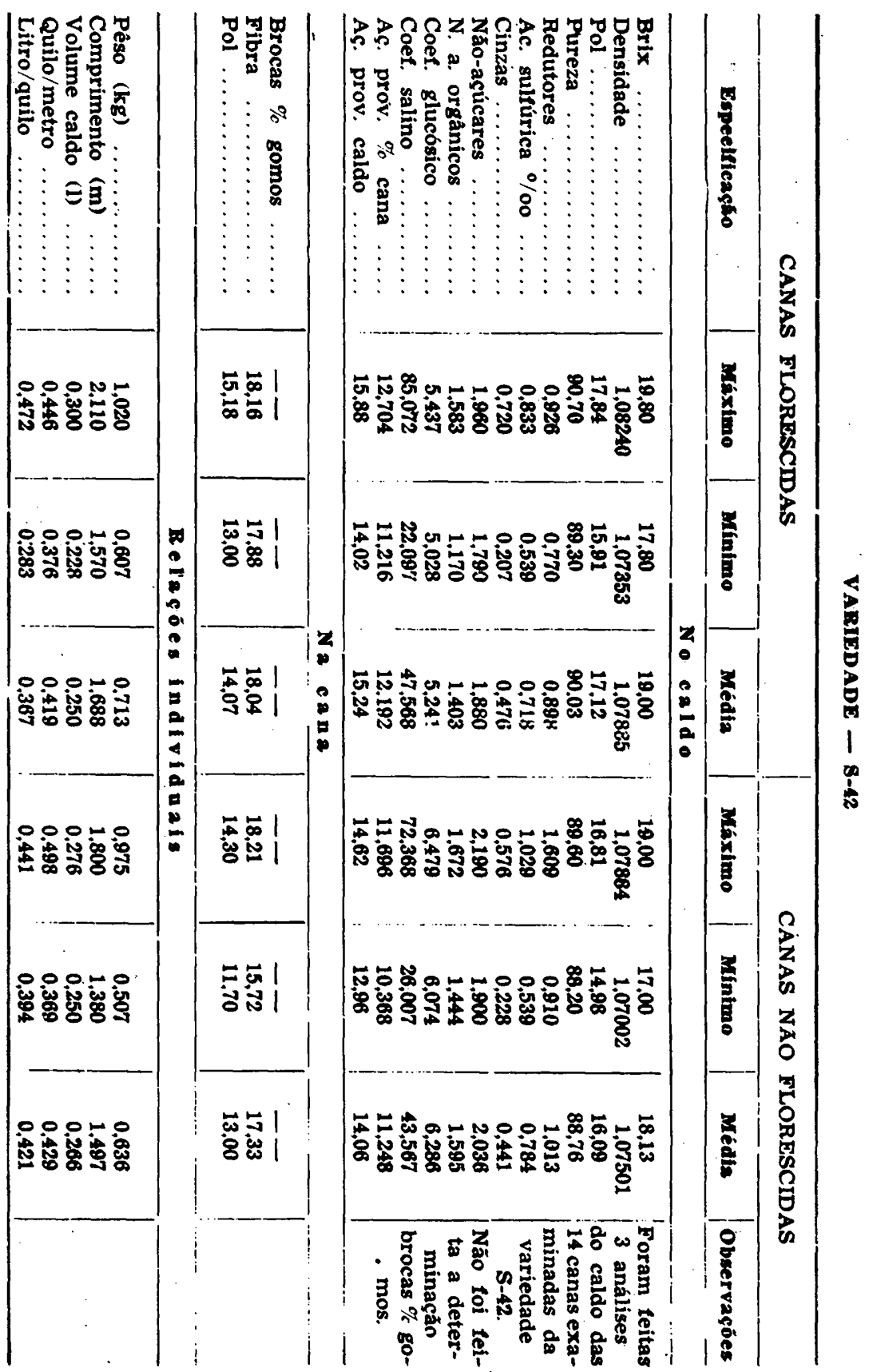




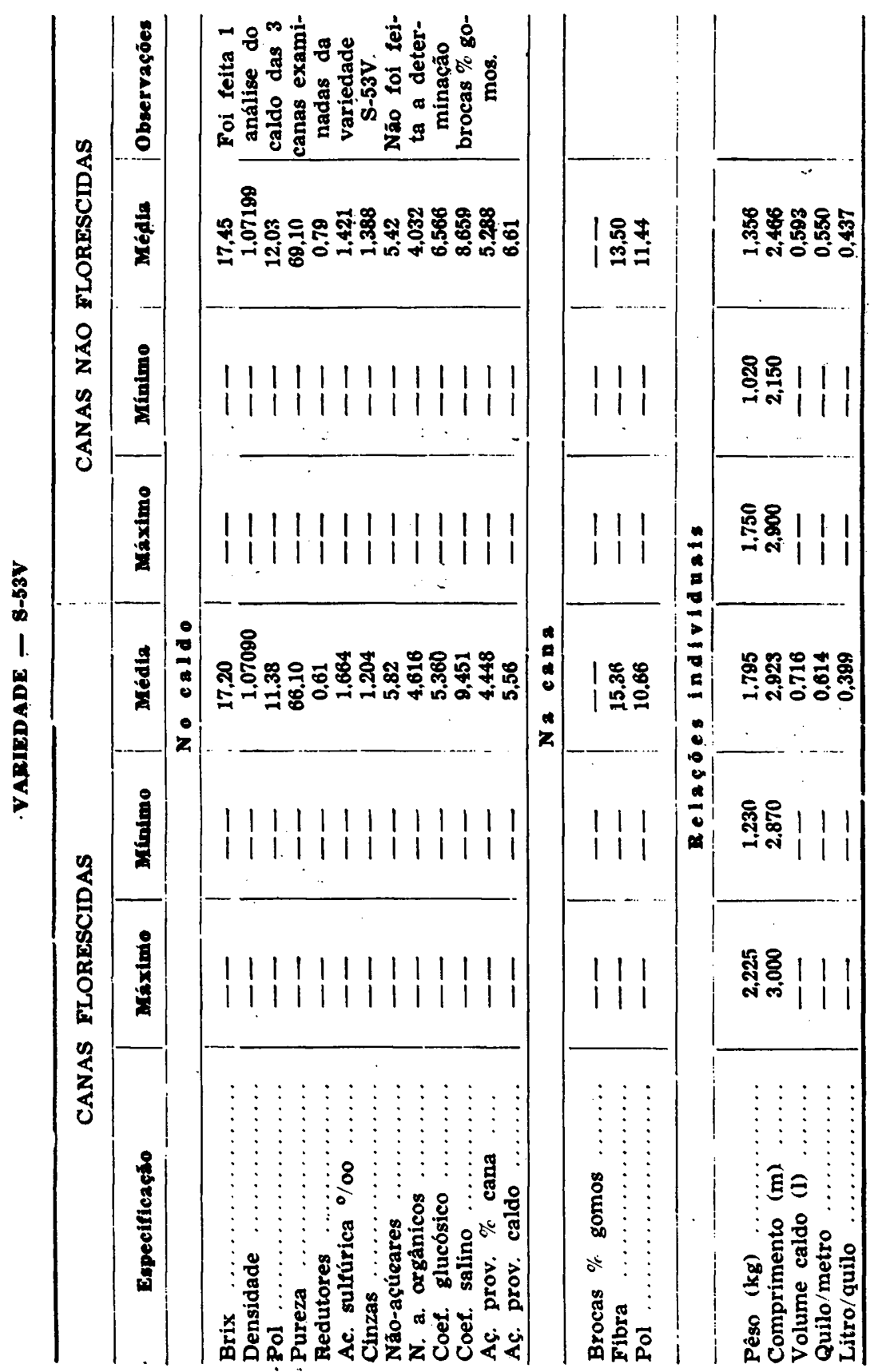




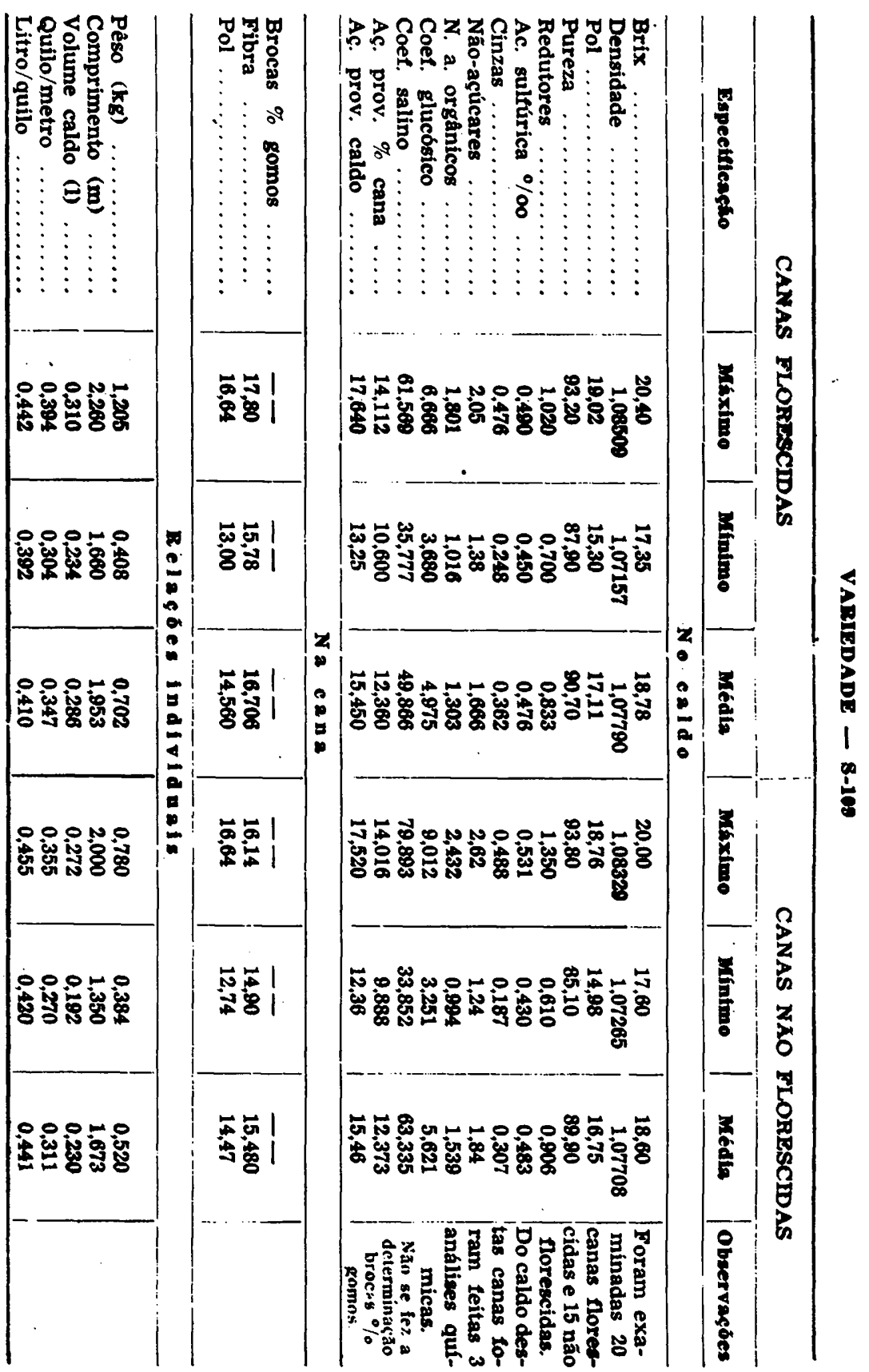




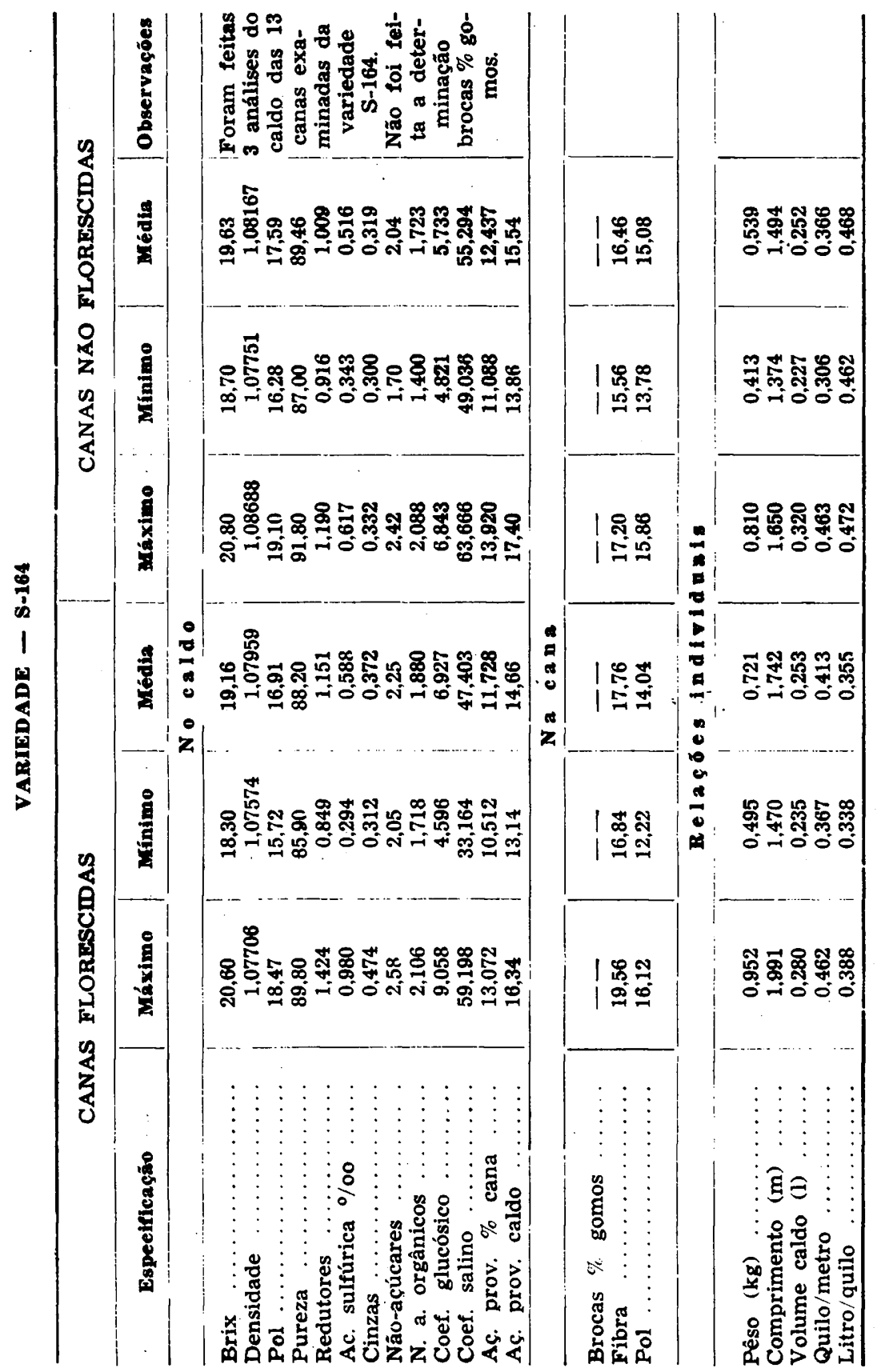




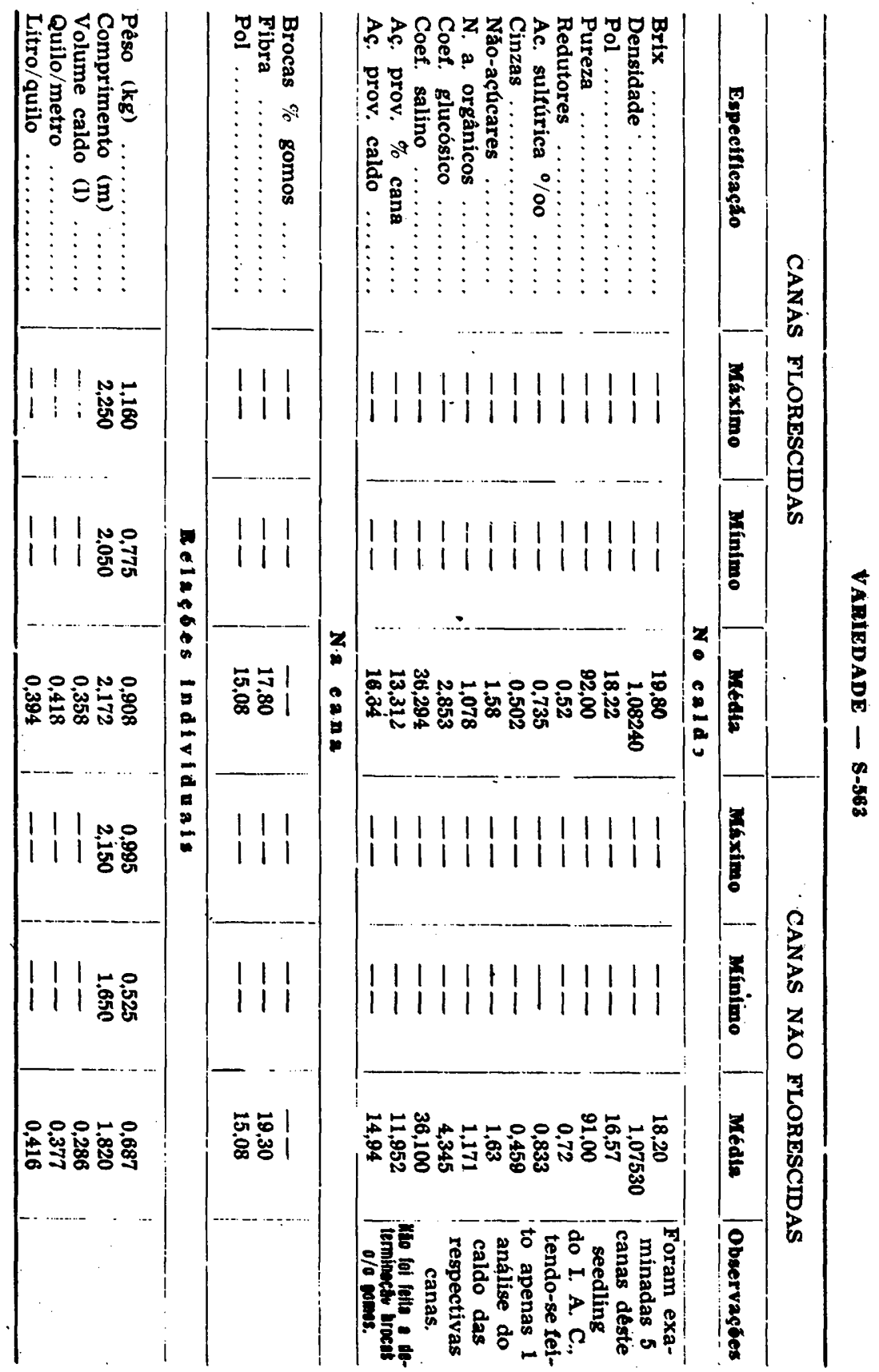




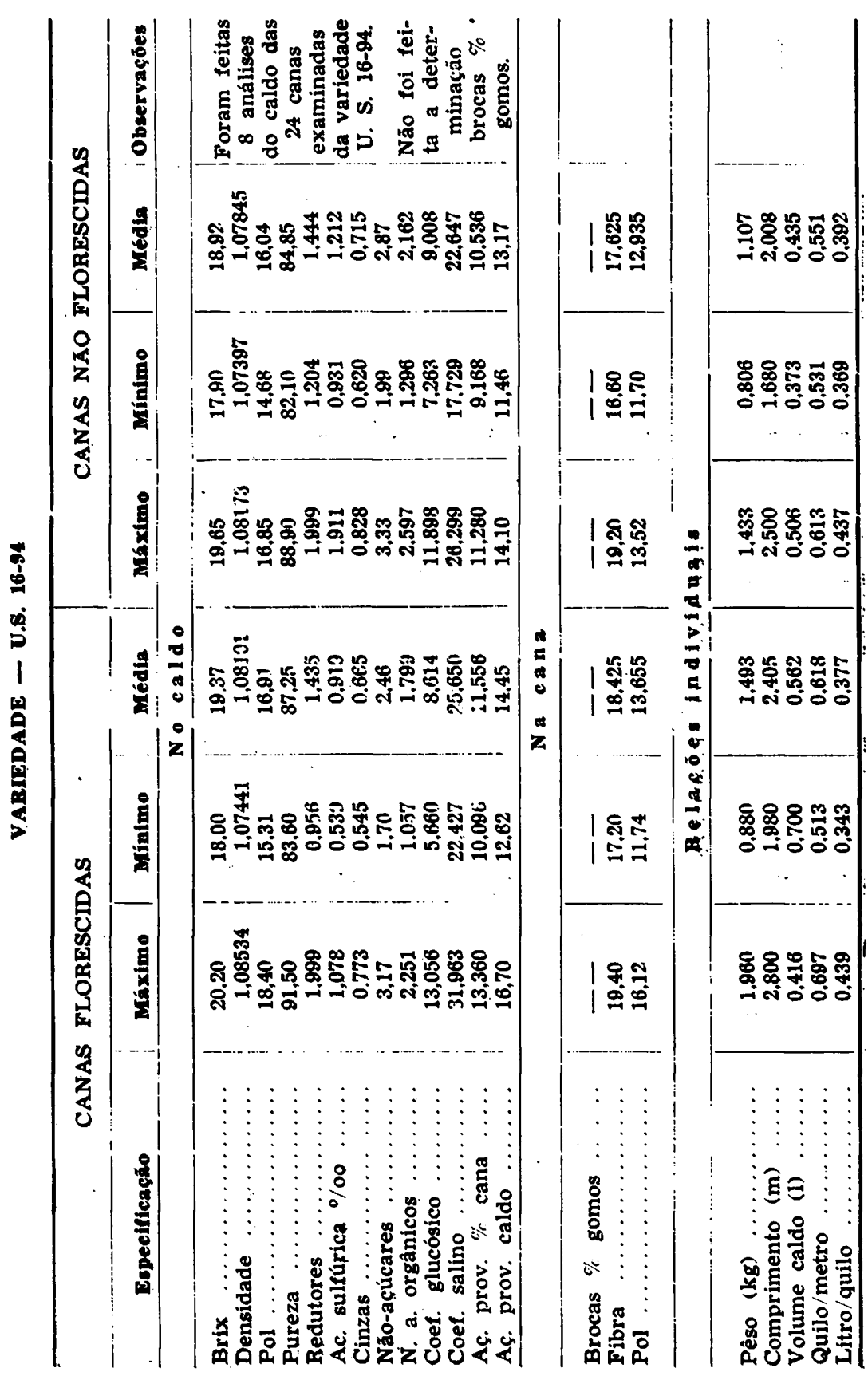




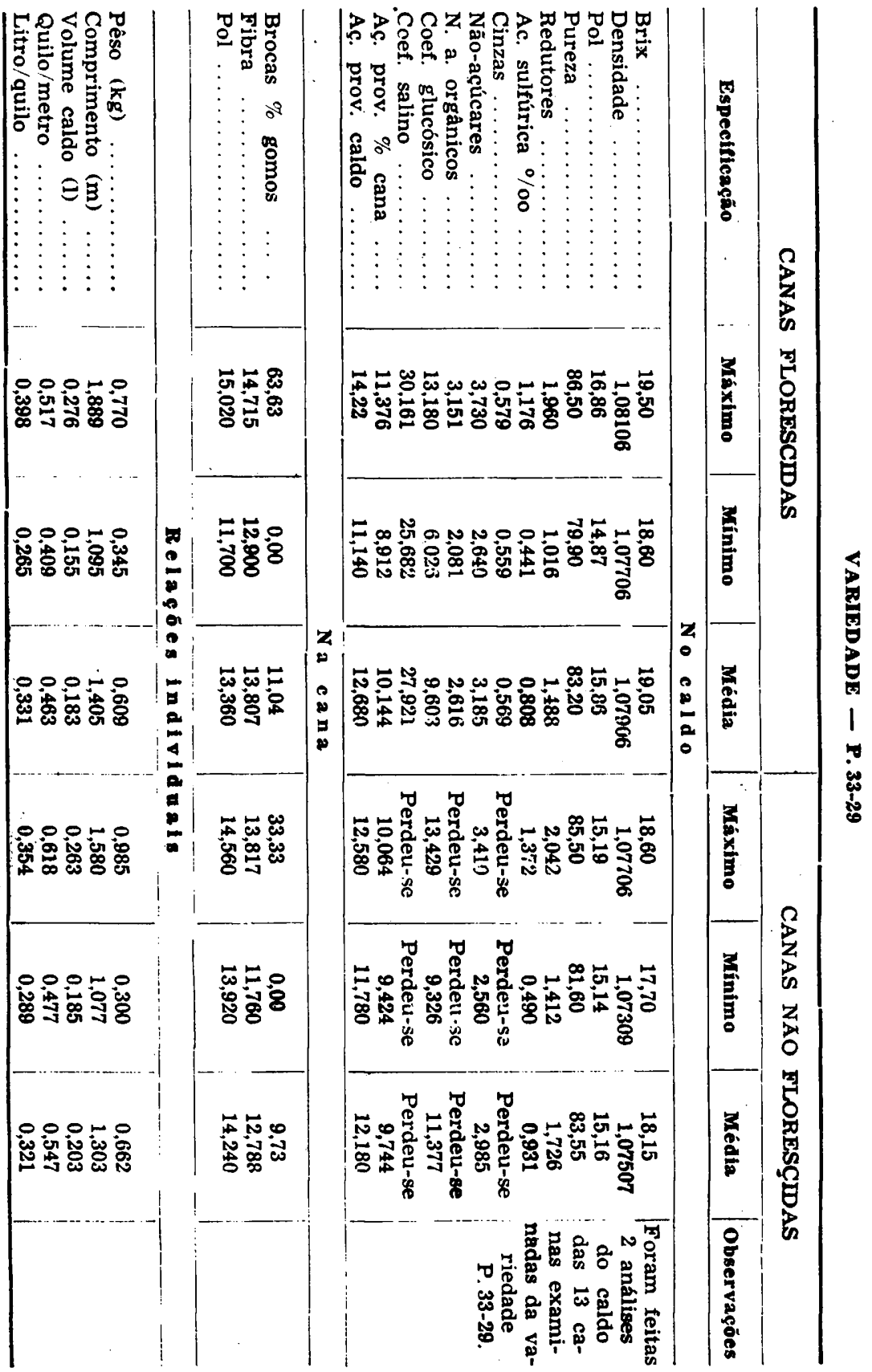




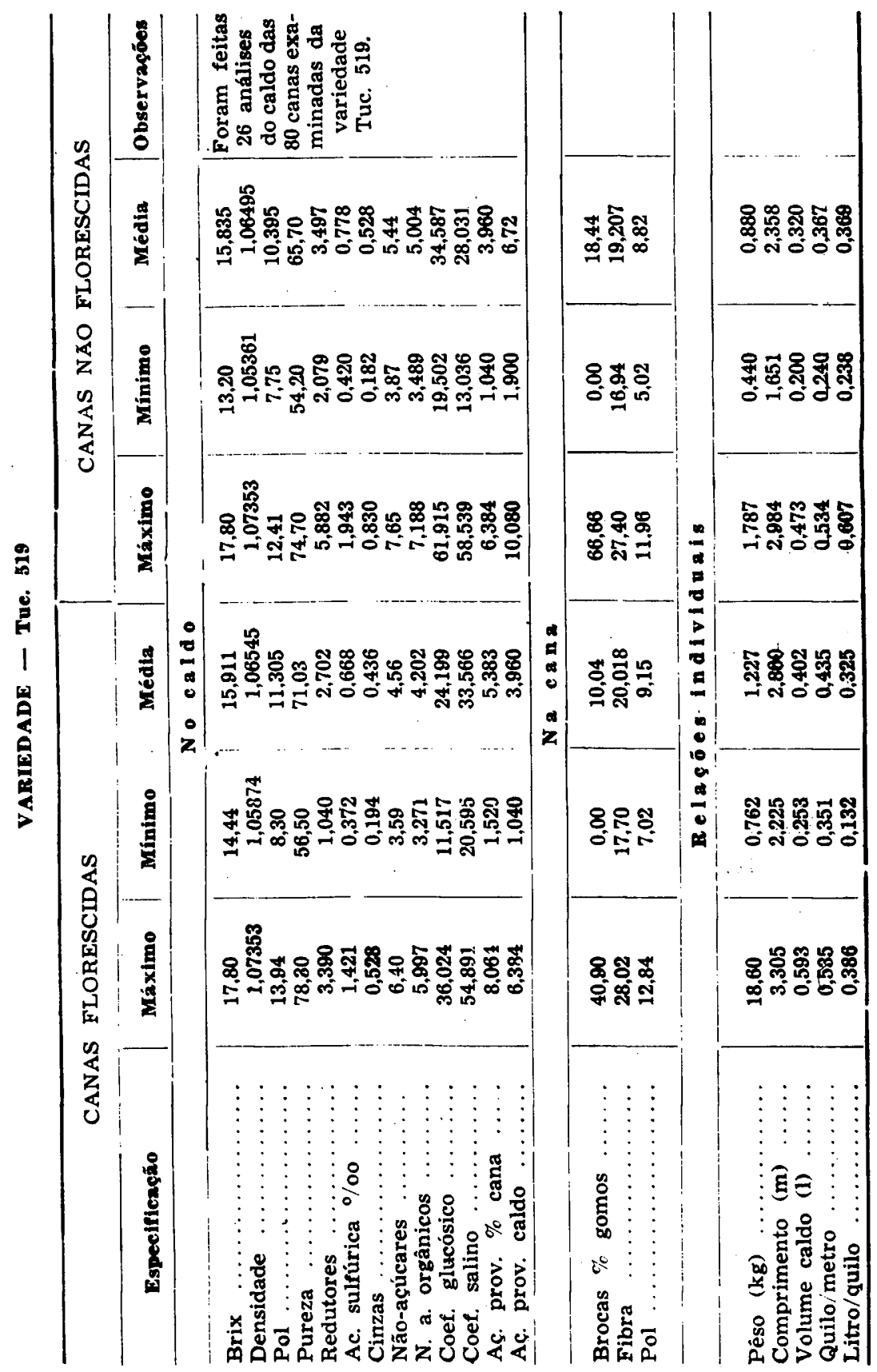




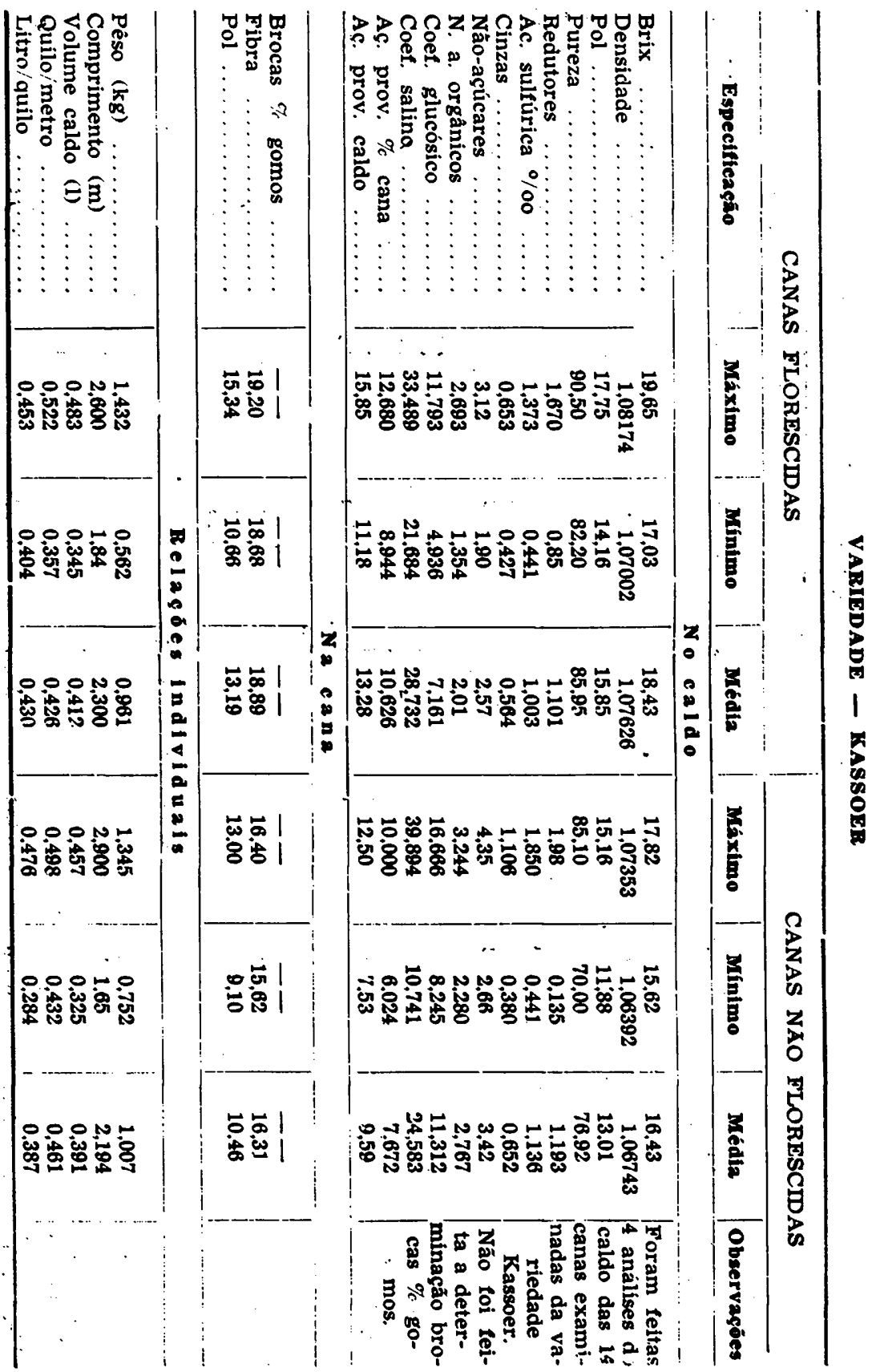




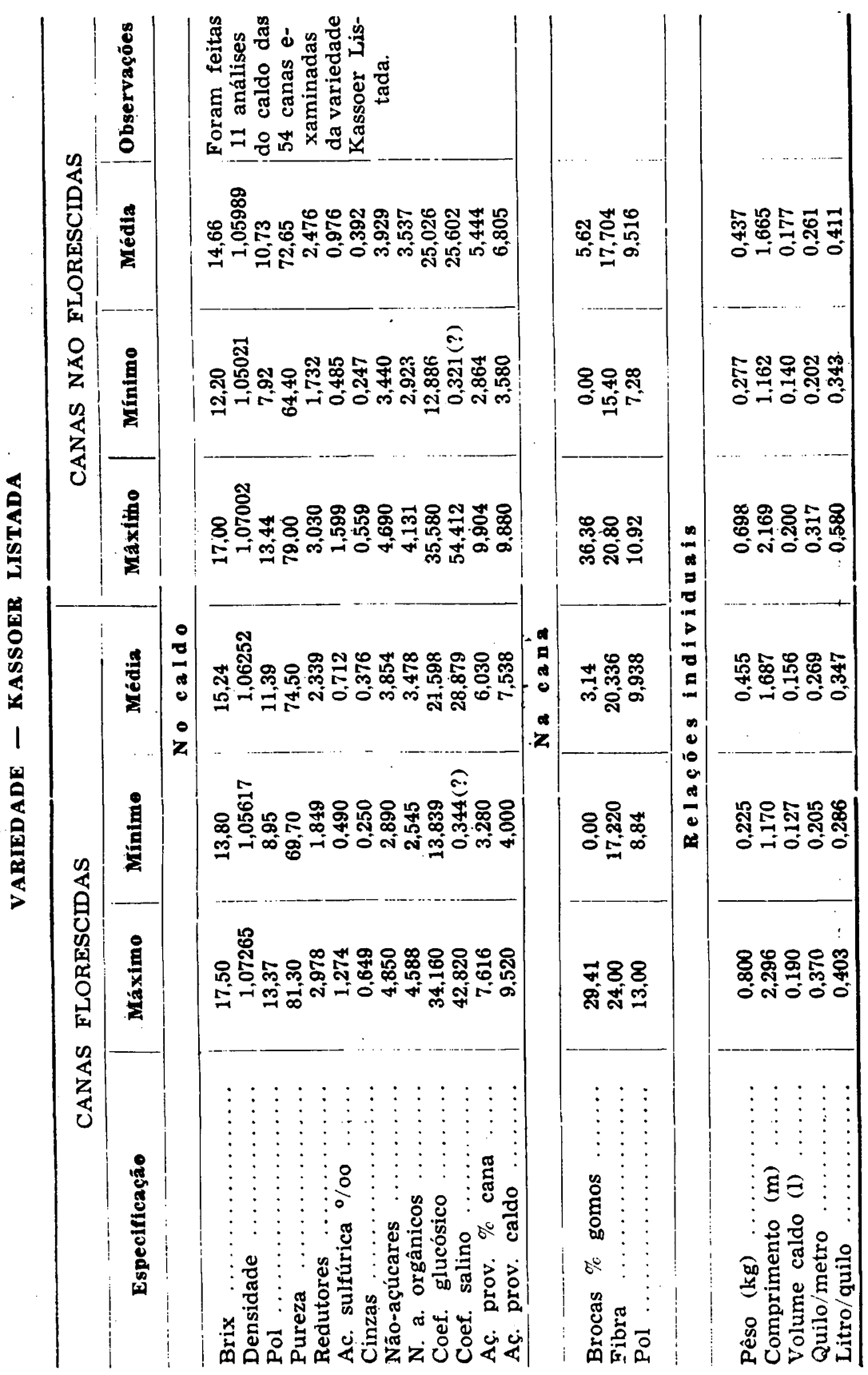


Anais da E. S. A. «Luir He Queiroz»

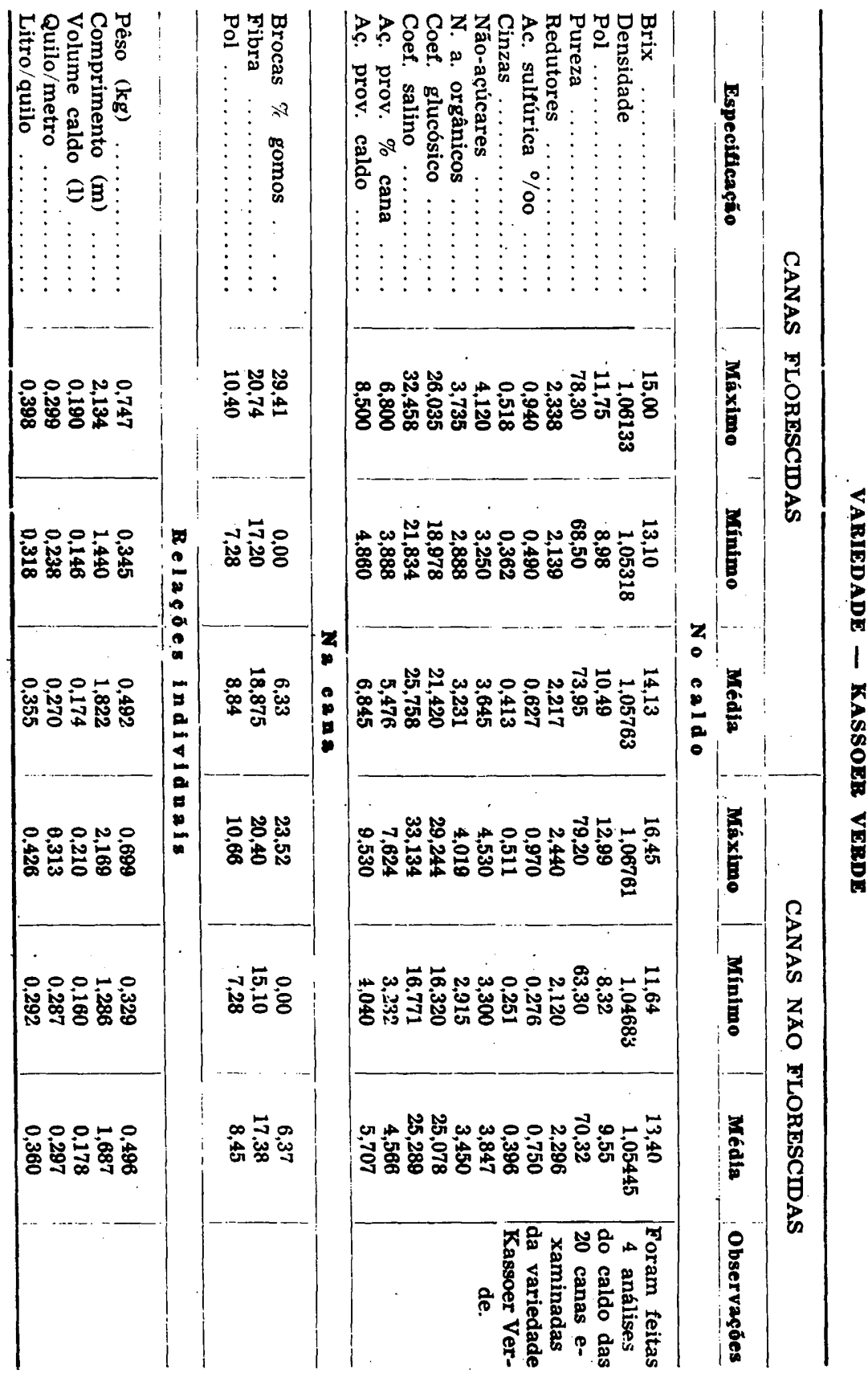




\section{BIBLIOGRAFIA}

AGUIRRE, José Manoel de - 1936 - Creação de novas variedades de cana no Estado de São Paulo - 1.0 Congr. Brasill. de Agron., Piracicaba.

ALEXANDER, W. P. - 1925 - A report on tasseling - Int. sugar Journ., n. 313, v. 27, p. 14.

ALLARD, H. A. - 1939 - The flowering of the sugar cane -Int. sugar Journ., n. 485 , v. 41 , p. 175.

ARTSCHWAGER, Ernst; BRANDES, E. W. e STARRETT, Ruth Colvin - 1931 - Development of flower and seed of some varieties of sugar cane - Int. sugar Journ., n. 395, v. 33, p. 535.

ANONIMO - 1942 - Flowering of cane in Louisiana - Int. sugar Journ., n. 525, v. 44.

BANNIER, J. P. - 1927 - The raising of seedling cana in Java - Int. sugar Journ., n. 337, v. 29, pgs. 18, 64 .

BARBER, C. A. - 1920 - Cane arrowing and the raising of seedlings. - Int. sugar Journ., n. 256, v. 22, p. 197.

BARBER, C. A. - 1920 - The growth of the sugar cane - Int. sugar Journ., pgs. 76, 198, 313, 371, 442, 495,548.

BARBER, C. A. - 1920 - Sugar cane seedling work in India Int. Sugar Journ., n. 257, v. 22, p. 251.

BARBER, C. A. - 1929 - Cane breeding work in Barbados Ini. sugar Journ., n. 366, v. 31, p. 294.

BARRETO, B. T. - 1936 - Notes on the flowering of cane Int. sugar Journ., n. 446, v. 38, p. 71.

BATHAM, H. N. e NIGAM, L. S. - 1936 - Flowering of Coimbatore cane in the U. P., India - Int. Sugar Journ., n. 452 , v. 38, p. 312 .

BRIEGER, Frederico G. - 1937 - Tábuas e fórmulas para estatística.

CHARDON, C. E. - 1928 - Experiencias sobre la caña POJ 2725 - Bul. 34, Est. Exp. Puerto Rico.

CROSS, William E. - 1933 - The flowering of sugar cane Int. Sugar Journ., n. 418, v. 35, p. 396.

DEERR, Noel - 1931 - Results and object lessons from a half century of cane breeding - Int. sugar Journ., n. 385, v. 33, p. 6.

DUTT, N. L.; KRISHNASWAMI, M. K. e RAO, K. S. Subba 1938 - On certain floral characters in sugar cane - Proc. of the Sixth Congres, La., p. 154. 
DUTT, N. L.; KRISHNASWAMI, M. K. e RAO, K. S. Subba 1939 - The taxonomy and physiology of flowering in the sugar cane - Int. sugar Journ., n. 488, v. 41, p. 296.

EARLE, F. S. - 1922 - Selection of varieties in cane cultivation - Int. sugar Journ., n. 281, v. 24, p. 236.

EVANS, H. - 1938 - Isolation of cane flowers in cane breeding work - Int. sugar Journ., n. 477, v. 40, p. 360.

FISHER, R. A. - 1932 - Statistical methods for research workers, 4.a ed..

GEERLIGS, H. C. Prinsen - 1924 - Cane sugar and its manufacture, 2.a ed., p. 71.

GHOSH, M. - 1926 - Flowering of sugar cane - Int. sugar Journ., n. 334, v. 28, p. 520.

GROBERT, H. de - 1921 - Premature going to flower of the sugar cane - Int. sugar Journ., n. 272, v. 23, p. 451.

II. M. L. - 1939 - The flowering of the sugar cane - Int. sugar Journ., n. 485, v. 41, p. 175.

JESWIET, J - 1929 - The flowering of sugar cane - 2d. An. Conf. of the Int. Soc. of sugar cane Techn..

KASHIBUCHI, $\mathrm{H}-1939$ - Investigations on the arrowing of sugar cane - Int. sugar Journ., n. 491, v. 41, p. 474.

KASHIBUCHI, H. - 1940 - Some investigations on the arrowinz of sugar cane plants - Int. sugar Journ., n. 504, v. 42, p. 427.

KERR, H. W. - 1941 - Does fertilizer affect the arrowing of cane? - Int. sugar Journ., n. 510 , v. 43, p. 188 .

KENNEY, John F. - 1943 - Mathematics of statistics, 4.a ed. MARKWELL, O. C. - 1925 - Tasseling - Int. sugar Journ., n. 324, v. 27, p. 651.

MEYER, Antonio Corréa - 1933 - A maturaçáo e o comportamento das novas variedades de cana introduzidas no Estado de Săo Paulo - Rev. de Agric..

PEMBERTON, C. E. - 1937 - Comparative hardness of tasselled versus untasselled canes - Int. sugar Journ., n. 461, v. 39, p. 189.

IRAO, K. K. e IYER, K. V. G. - 1937 - Effect of arrowing on cane crops - Int. sugar Journ., n. 457, v. 39, p. 26.

REYNOSO, Alvaro - 1925 - Ensaio sobre el cultivo de la caffa de azucar, $4 a$ ed..

RODRIGUES, Milton da Silva - 1934 - Elementos de estatística geral.

SARTORIS, G. B. - 1938 - The behavior of sugarcane in relation to length of day - Proc. of the Sixth Congress, La., p. 796. 
SARTORIS, G. B. - 1939 - Factors controlling flowering Int. sugar Journ. n. 488, v. 41, p. 298.

SNEDECOR, George W. - 1940 - Statistical methods, 3.a ed. TIMPENFELD, P. - 1942 - Tablas de los cuadrados de 1 a 15.000 , cubos de 1 a 3.000 , raices cuadradas y cubicas de 1 a 1.200, circunferencias de circulos y superficies de 1 a 12.000 .

TRICANICO, Sylvio - 1931 - Condições para a formação das flores nos vegetais - Rev. de Agric., v. 6, n. 11-12, p. 415.

VENKATRAMAN, T. S. e THOMAS, R. - 1927 - Sugar cane breeding technique: isolation of live arrows from undesidered pollen through artificial rooting of canes - Int. sugar Journ., n. 343, v. 29, p. 362.

VENKATRAMAN, T. S. e THOMAS, R. - 1931 - Report of the government sugar cane expert - Int. sugar Journ., n. 394, v. 33, p. 492.

VENKATRAMAN, T. S. e THOMAS, R. - 1931 - Controlling time of flowering - Int. sugar Journ., n. 394, v. 33, p. 498.

VIZIOLI, José - 1929 - O florescimento da cana de açúcar no Estado de São Paulo - Sec. Agric. Ind. Com. do Est. de S. Paulo.

WISHART e SANDERS - 1936 - Princípios e prática da experimentação de campo - Trad. de G. P. Viegas.

YAMASAKI, Morimasa e ODA, Hiroshi - 1938 - On the arrowing tendency of sugarcanes along the edges of the fields - Proc. of the Sixth Cong., La., p. 793. 